\title{
Exploring the controls on element ratios in middle Eocene samples of the benthic foraminifera Oridorsalis umbonatus
}

\author{
C. F. Dawber ${ }^{1}$ and A. K. Tripati ${ }^{2,3,4}$ \\ ${ }^{1}$ Department of Earth Sciences, University of Cambridge, Downing Street, Cambridge, CB1 2EQ, UK \\ ${ }^{2}$ Department of Earth and Space Sciences, University of California, Los Angeles, USA \\ ${ }^{3}$ Department of Atmospheric and Oceanic Sciences, University of California, Los Angeles, USA \\ ${ }^{4}$ Institute of the Environment and Sustainability, University of California, Los Angeles, USA \\ Correspondence to: C. F. Dawber (dawber.caroline@gmail.com) and A. K. Tripati (ripple@zephyr.ess.ucla.edu) \\ Received: 6 October 2011 - Published in Clim. Past Discuss.: 11 November 2011 \\ Revised: 8 October 2012 - Accepted: 16 October 2012 - Published: 7 December 2012
}

\begin{abstract}
Culturing studies and empirically based core top calibrations have been used to infer that elemental ratios in benthic foraminifera can be used as proxies to reconstruct past variations in bottom water temperature and saturation state $\left(\Delta\left[\mathrm{CO}_{3}^{2-}\right]\right)$. However the mechanisms linking elemental ratios to these parameters are poorly constrained. Here, we explore the environmental parameters influencing the incorporation of $\mathrm{B}, \mathrm{Li}, \mathrm{Sr}$ and $\mathrm{Mg}$ in Oridorsalis umbonatus in early Cenozoic sediments from Ocean Drilling Program Site 1209. We investigate the influence of middle Eocene variations in intermediate water $\Delta\left[\mathrm{CO}_{3}^{2-}\right]$ using relationships developed from core top samples. The fidelity of bottom water $\Delta\left[\mathrm{CO}_{3}^{2-}\right]$ reconstructions based on single element ratios is assessed by comparing the $\mathrm{X} / \mathrm{Ca}$-based reconstructions to each other and to carbon cycle proxy records (benthic foraminifera $\delta^{13} \mathrm{C}$, organic carbon content, foraminifera dissolution indices), and a seawater $\delta^{18} \mathrm{O}$ reconstruction for Site 1209. Discrepancies in the reconstructed $\Delta\left[\mathrm{CO}_{3}^{2-}\right]$ values based on these different metal ratios suggest that there are still gaps in our understanding of the parameters influencing $\mathrm{X} / \mathrm{Ca}$ and demonstrate that caution is required when interpreting palaeo-reconstructions that are derived from a single elemental ratio. The downcore record of $O$. umbonatus $\mathrm{Mg} / \mathrm{Ca}$ does not exhibit any similarities with the $\mathrm{Li} / \mathrm{Ca}, \mathrm{B} / \mathrm{Ca}$ and $\mathrm{Sr} / \mathrm{Ca}$ records, suggesting that the environmental parameters influencing $\mathrm{Mg} / \mathrm{Ca}$ may be different for this species, consistent with temperature as the strongest control on this elemental ratio. This hypothesis is supported by the coefficients of multiple linear regression models on published $\mathrm{Mg} / \mathrm{Ca}$ data. An incomplete understanding of the controls
\end{abstract}

on elemental incorporation into benthic foraminifera hinders our ability to confidently quantify changes in saturation state using single $\mathrm{X} / \mathrm{Ca}$ reconstructions over a range of timescales.

\section{Introduction}

Model simulations and proxy-based reconstructions hypothesise that early Cenozoic glaciation was closely linked to variations in the global carbon cycle (DeConto and Pollard, 2003; Coxall et al., 2005; Tripati et al., 2005, 2008; Riesselman et al., 2007; DeConto et al., 2008; Merico et al., 2008; Pearson et al., 2009; Spofforth et al., 2010; Coxall and Wilson, 2011). Large (>1\%o) shifts in planktonic, benthic and seawater oxygen isotope ratios and in the accumulation of ice-rafted debris during the middle Eocene to earliest Oligocene (Oi-1) are synchronous with substantial ( $>500 \mathrm{~m}$ ) variations in the depth of the calcite compensation depth (CCD) and in the $\delta^{13} \mathrm{C}$ of benthic foraminifera (Coxall et al., 2005; Tripati et al., 2005, 2008; Riesselman et al., 2007; Edgar et al., 2007; Coxall and Wilson, 2011). In order to better define the relationship between global climate, glaciation and the carbon cycle, it is necessary to have proxies for seawater carbonate system parameters. Such proxies are particularly useful because on timescales greater than $10^{4} \mathrm{yr}$, but less than $10^{6}-10^{8} \mathrm{yr}$, the oceanic inventory and distribution of carbon is thought in part to be responsible for regulating atmospheric $p \mathrm{CO}_{2}$. 
Recently a number of empirically based studies have demonstrated that elemental ratios in benthic foraminifera $(\mathrm{Mg} / \mathrm{Ca}, \mathrm{Li} / \mathrm{Ca}, \mathrm{B} / \mathrm{Ca}, \mathrm{U} / \mathrm{Ca})$ exhibit positive correlations with bottom water carbonate saturation $\left(\Delta\left[\mathrm{CO}_{3}^{2-}\right]\right.$, where $\Delta\left[\mathrm{CO}_{3}^{2-}\right]$ is the difference between in situ and saturation $\left[\mathrm{CO}_{3}^{2-}\right]$ (e.g. Elderfield et al., 2006; Rosenthal et al., 2006; Yu and Elderfield, 2007, 2008; Dawber and Tripati, 2012; Lear et al., 2010; Rae et al., 2011; Brown et al., 2011). If the sensitivity of element/calcium $(\mathrm{X} / \mathrm{Ca})$ ratios remains constant through time, reconstructions of deep water $\Delta\left[\mathrm{CO}_{3}^{2-}\right]$ may help better define links between glaciation and atmospheric $p \mathrm{CO}_{2}$. At present, the underlying mechanistic cause of the observed relationships between foraminifera $\mathrm{X} / \mathrm{Ca}$ and bottom water $\Delta\left[\mathrm{CO}_{3}^{2-}\right]$ is poorly constrained and differs significantly between species. Indeed, for some species including $O$. umbonatus, different core top relationships have been reported (Dawber and Tripati, 2012, Brown et al., 2011). It is not clear whether these discrepancies reflect differences in data acquisition methods and/or sample size, or perhaps indicate the influence of secondary parameters, including but not limited to temperature and post-depositional preservation. Dawber and Tripati (2012) discuss some of the possible reasons for differences in empirically derived relationships from core tops.

Several types of studies can better resolve the nature of relationships between benthic foraminiferal $\mathrm{X} / \mathrm{Ca}$ ratios and hydrographic parameters such as bottom water $\Delta\left[\mathrm{CO}_{3}^{2-}\right]$ and temperature. One approach that can be used is as described above - i.e. examining empirically derived relationships from core top samples in the context of biomineralisation models and constraints from culture studies (e.g. Dawber and Tripati, 2012). However, deep-sea benthic foraminifera are notoriously difficult to culture in the lab, and, as a result, this approach is mostly conceptual and relies heavily on a framework derived using observations from inorganic precipitation experiments and planktonic foraminifera culturing studies, which may or may not be appropriate for benthic foraminifera. A second approach is to expand core top datasets (both the sample size and study regions used) to better characterize relationships between X/Ca and multiple hydrographic parameters. However the covariation of several hydrographic parameters means that it may not be possible to accurately attribute $\mathrm{X} / \mathrm{Ca}$ data for geological samples to hydrographic parameters. A third approach, and the one explored herein, is to test the hypothesis that core top-derived relationships can accurately and consistently estimate past variations in environmental parameters for periods and locations for which auxiliary environmental and seawater chemistry proxy data are available to falsify reconstructions.

Below we present new and published (Dawber and Tripati, 2011) element ratio data $(\mathrm{B} / \mathrm{Ca}, \mathrm{Li} / \mathrm{Ca}, \mathrm{Sr} / \mathrm{Ca}$ and $\mathrm{Mg} / \mathrm{Ca})$ for the infaunal benthic foraminifera Oridorsalis umbonatus in sediment samples from Ocean Drilling Program (ODP) Site 1209 in the Pacific Ocean. The X/Ca records span the middle
Eocene, a critical interval of the early Cenozoic "greenhouseicehouse" transition. ODP Site 1209 was located at an intermediate water depth during the Eocene. We explore the sensitivity of the element ratio records to a number of parameters including bottom water $\Delta\left[\mathrm{CO}_{3}^{2-}\right]$, temperature, seawater composition, post-depositional preservation and pore water chemistry by comparing the $\mathrm{X} / \mathrm{Ca}$ records to each other, and to additional carbon cycle proxy records and a reconstruction of seawater oxygen isotope values. We also estimate bottom water $\Delta\left[\mathrm{CO}_{3}^{2-}\right]$ and temperature at Site 1209 using multielement ratios and global minimization solutions.

\section{Materials and methods}

\subsection{Locality information, age model, and sample preservation}

Ocean Drilling Program (ODP) Site 1209 (32 39.108' N, $158^{\circ} 30.3564^{\prime}$ E) was located in the northern subtropical Pacific Ocean throughout the middle Eocene, with an estimated paleodepth of $\sim 1.9-2.5 \mathrm{~km}$ (Dutton et al., 2005; Bohaty et al., 2009). Site 1209 was above the Eocene CCD (Tripati et al., 2005), although carbonate preservation may have been influenced by the relatively shallow Pacific lysocline at this time (Hancock and Dickens, 2005).

Chronostratigraphic datums for Site 1209 are based on biostratigraphic markers and indicate that the studied interval (140-164 revised meters composite depth, rmcd) is middle Eocene in age (Bralower, 2005; Petrizzo et al., 2005). We use the "best-guess" age model for Site 1209 reported in Dawber and Tripati (2011) but note that, due to high planktonic fragmentation in parts of the studied interval and the regional diachrony of middle Eocene calcareous nannofossil datums (Petrizzo et al., 2005; Bohaty et al., 2009), there may be some uncertainty associated with the age model. The age model may be subject to reinterpretation if biostratigraphical datums are later revised. In light of these potential uncertainties, we restrict any comparisons of foraminifera $\mathrm{X} / \mathrm{Ca}$ to sites in the Pacific Basin.

Specimens of $O$. umbonatus become increasingly fragmented in the upper part of the studied interval. Care was taken to select the best-preserved specimens for analysis. Although specimens did not exhibit the "glassy" appearance sometimes observed in clay-rich, shallow continental shelf environments, these deep-sea specimens did not exhibit the chalky appearance described to reflect significant postdepositional alteration (Sexton et al., 2006). Scanning electron micrograph (SEM) images for O. umbonatus tests are available in Dawber and Tripati (2011).

\subsection{Geochemical analyses and data acquisition}

Element/calcium ratios were measured on specimens of Oridorsalis umbonatus picked from the $>150 \mu \mathrm{m}$ size fraction $(n=8-20$ specimens). Samples were processed and 
cleaned for contaminating phases using an oxidative procedure that is based on Barker et al. (2003). All downcore $\mathrm{B} / \mathrm{Ca}$ and $\mathrm{Li} / \mathrm{Ca}$ ratios and some $\mathrm{Mg} / \mathrm{Ca}$ and $\mathrm{Sr} / \mathrm{Ca}$ ratios were determined from matrix-matched intensity ratios on Perkin Elmer Elan DRC II, a quadrupole inductively coupled plasma mass spectrometer (Q-ICP-MS) at the University of Cambridge, following the procedure of $\mathrm{Yu}$ et al. (2005) at a $\mathrm{Ca}^{2+}$ concentration of $100 \mathrm{ppm}$. Additional downcore $\mathrm{Mg} / \mathrm{Ca}$ and $\mathrm{Sr} / \mathrm{Ca}$ measurements were made using a Varian Vista inductively coupled plasma atomic emission spectrophotometer (ICP-AES) following the method of de Villiers et al. (2002). These two methods yield consistent $\mathrm{Sr} / \mathrm{Ca}$ and $\mathrm{Mg} / \mathrm{Ca}$ results based on long-term dual measurements (Greaves, personal communication, 2012) All data were screened for contaminating phases using ancillary element ratios (i.e. $\mathrm{Al} / \mathrm{Ca}, \mathrm{Fe} / \mathrm{Ca}, \mathrm{Si} / \mathrm{Ca}, \mathrm{Mn} / \mathrm{Ca}$ ). Any samples that fell outside the range reported by Barker et al. (2003, e.g. $\mathrm{Fe} / \mathrm{Mg}$ ratios of $>0.1 \mathrm{~mol} \mathrm{~mol}^{-1}$ ) were excluded. We routinely achieved the analytical accuracy and precision on the $\mathrm{X} / \mathrm{Ca}$ ratios reported by $\mathrm{Yu}$ et al. (2005). Longterm instrumental precisions of $\mathrm{Li} / \mathrm{Ca}$ and $\mathrm{B} / \mathrm{Ca}$ determined by quadrupole ICP-MS are $2.2 \%$ and $3.6 \%$ respectively, based on replicate analyses of standard solutions containing $\mathrm{Li} / \mathrm{Ca}=10 \mu \mathrm{mol} \mathrm{mol}^{-1}$ and $\mathrm{B} / \mathrm{Ca}=60 \mu \mathrm{mol} \mathrm{mol}^{-1}$ during the period 2005-2010 (Greaves, personal communication, 2012). Instrumental precisions of $\mathrm{Mg} / \mathrm{Ca}$ and $\mathrm{Sr} / \mathrm{Ca}$ determined by Vista ICP-AES are $0.46 \%$ and $0.34 \%$ respectively based on replicate analyses of standard solutions containing $\mathrm{Mg} / \mathrm{Ca}=1.289 \mathrm{mmol} \mathrm{mol}^{-1}$ and $\mathrm{Sr} / \mathrm{Ca}=0.808 \mathrm{mmol} \mathrm{mol}^{-1}$ during the period 2002-2010 (Greaves, personal communication, 2012). Note the absence of $\mathrm{Li} / \mathrm{Ca}$ and $\mathrm{B} / \mathrm{Ca}$ measurements prior to $41 \mathrm{Ma}$ is is due to the timing of Site 1209 analyses with respect to the development of the $\mathrm{B} / \mathrm{Ca}$ and $\mathrm{Li} / \mathrm{Ca}$ acquisition method at Cambridge University. It does not reflect issues with the core material or data quality, and was not through experimental design.

Foraminiferal dissolution indices are from Dawber and Tripati (2011). The weight percentage of organic carbon was calculated using the "loss on ignition" principal (e.g. Heiri et al., 2001). O. umbonatus $\delta^{13} \mathrm{C}$ measurements were made on a homogenized sub-sample of the specimens used to determine $\mathrm{Mg} / \mathrm{Ca}$ and $\mathrm{Sr} / \mathrm{Ca}$ via ICP-AES (but separate to X/Ca analyses via Q-ICP-MS). Carbon isotope ratios were determined on two gas source mass spectrometers in the Department of Earth Sciences, University of Cambridge. Long-term analytical precision based on replicate analyses of an in-house standard is $0.06 \%$. Seawater $\delta^{18} \mathrm{O}$ estimates are from Dawber and Tripati (2011).

\section{Results}

\section{Middle Eocene $\mathrm{X} / \mathrm{Ca}$ ratios}

Records of $O$. umbonatus $\mathrm{Li} / \mathrm{Ca}, \mathrm{B} / \mathrm{Ca}, \mathrm{Mg} / \mathrm{Ca}$ and $\mathrm{Sr} / \mathrm{Ca}$ (Fig. 1) display large amplitude variations on short and long timescales during the middle Eocene (up to $25 \%$ in $\Delta \mathrm{Sr} / \mathrm{Ca}$, $30 \%$ in $\Delta \mathrm{Li} / \mathrm{Ca}, 40 \%$ in $\Delta \mathrm{Mg} / \mathrm{Ca}$ and $56 \%$ in $\Delta \mathrm{B} / \mathrm{Ca})$. On short timescales ( $<1$ million years), B/Ca ratios do not exhibit any statistically significant correlation with the $\mathrm{Li} / \mathrm{Ca}$, $\mathrm{Mg} / \mathrm{Ca}$ or $\mathrm{Sr} / \mathrm{Ca}$ records (Fig. 1).

$\mathrm{Sr} / \mathrm{Ca}$ and $\mathrm{Mg} / \mathrm{Ca}$ records span $\sim 37-45 \mathrm{Ma}$, with additional estimates from $\mathrm{Li} / \mathrm{Ca}$ and $\mathrm{B} / \mathrm{Ca}$ between $\sim 41-37 \mathrm{Ma}$. Between $\sim 38.7$ and $37 \mathrm{Ma}, \mathrm{Sr} / \mathrm{Ca}$ and $\mathrm{Li} / \mathrm{Ca}$ increase, while $\mathrm{B} / \mathrm{Ca}$ and $\mathrm{Mg} / \mathrm{Ca}$ records show no net change. Furthermore, the structure of the $\mathrm{B} / \mathrm{Ca}$ and $\mathrm{Mg} / \mathrm{Ca}$ records is notably different (Fig. 1). On long timescales (45-37 Ma) the $\mathrm{Sr} / \mathrm{Ca}$ and $\mathrm{Mg} / \mathrm{Ca}$ decline; however, during this period there are significant differences in the amplitude and structure of the $\mathrm{Sr} / \mathrm{Ca}$ and $\mathrm{Mg} / \mathrm{Ca}$ records on shorter timescales ( $<1$ million years).

\section{Discussion}

\subsection{Influence of environmental parameters on middle Eocene $\mathrm{X} / \mathrm{Ca}$ records}

The X/Ca records for O. umbonatus at Site 1209 do not exhibit consistent trends throughout the middle Eocene. These observations demonstrate that there are likely multiple influences on $\mathrm{X} / \mathrm{Ca}$ in $O$. umbonatus and emphasize that caution needs to be taken when applying empirical core top relationships for this species either in isolation (i.e. for a single $\mathrm{X} / \mathrm{Ca}$ ) or using a multi-element approach to downcore reconstructions. Comparing the Site 1209 X/Ca records with other proxy records, we explore possible environmental influences and their relative contributions to the different X/Ca.

\subsubsection{Bottom water $\Delta\left[\mathrm{CO}_{3}^{2-}\right]$}

Quantifying changes in $\Delta\left[\mathrm{CO}_{3}^{2-}\right]$ in the early Cenozoic using single $\mathrm{X} / \mathrm{Ca}$ records and comparison to other proxy indices

One approach for assessing the relative influence of bottom water $\Delta\left[\mathrm{CO}_{3}^{2-}\right]$ on past variations in $O$. umbonatus $\mathrm{X} / \mathrm{Ca}$ is to take the empirical core top relationships at face value (Table 1), apply them to downcore $\mathrm{X} / \mathrm{Ca}$ records, and evaluate whether or not the estimated bottom water $\Delta\left[\mathrm{CO}_{3}^{2-}\right]$ values are reasonable and consistent with existing carbonate system proxy data. If the sensitivity of $\mathrm{X} / \mathrm{Ca}$ to $\Delta\left[\mathrm{CO}_{3}^{2-}\right]$ established from modern core top samples is assumed to be appropriate for the middle Eocene, the X/Ca records for Site $1209 \mathrm{im}$ ply significant changes in intermediate water $\Delta\left[\mathrm{CO}_{3}^{2-}\right]$ between 45 and $37 \mathrm{Ma}$. For example, the increase in $\mathrm{Sr} / \mathrm{Ca}$ and 

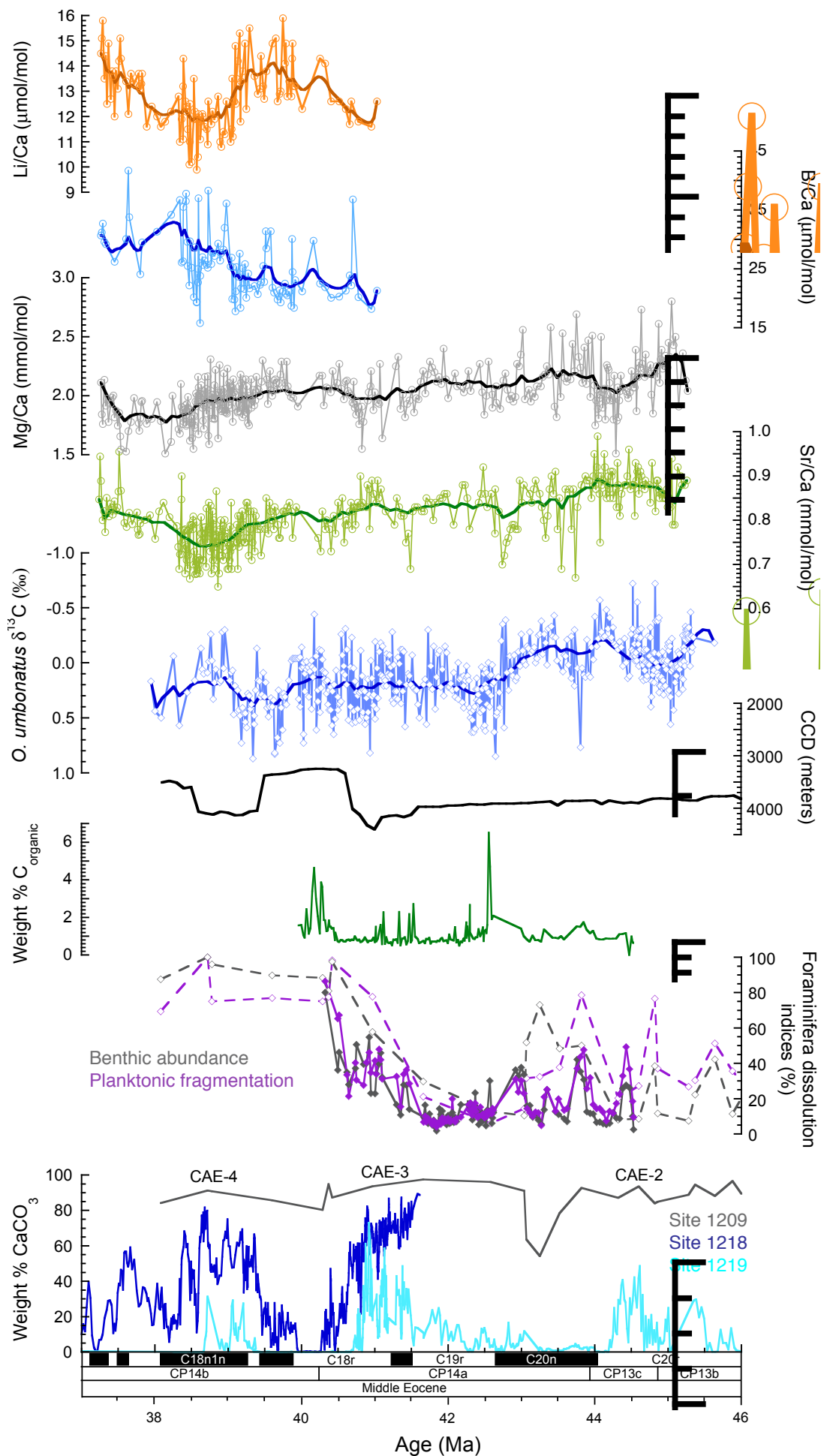

Fig. 1. Comparison of high-resolution middle Eocene records of $O$. umbonatus $\mathrm{Li} / \mathrm{Ca}, \mathrm{B} / \mathrm{Ca}, \mathrm{Mg} / \mathrm{Ca}$ and $\mathrm{Sr} / \mathrm{Ca}$ from ODP Site 1209 , equatorial Pacific Ocean with other carbonate system proxies. Heavier lines on X/Ca records denote a weighted smoothing function. Benthic abundance $(\%)$ and planktonic fragmentation, proxies for carbonate dissolution, are shown in grey and pink respectively; solid lines denote data from this study, and dashed lines are data from Hancock and Dickens (2005). Differences in absolute values reflect the different size fractions used to define the "coarse" fraction. The records of weight percentage of $\mathrm{CaCO}_{3}$ are from Hancock and Dickens (2005), Tripati et al. (2005) and Lyle et al. (2005). CAE is an abbreviation for the carbonate-accumulation events documented by Lyle et al. (2005). The calcite compensation depth (CCD) reconstruction for the Pacific Basin is from Tripati et al. (2005). 
$\mathrm{Li} / \mathrm{Ca}$ between $\sim 38.7$ and $37 \mathrm{Ma}$ may indicate a change in $\Delta\left[\mathrm{CO}_{3}^{2-}\right]$ of up to $60-85 \mu \mathrm{mol} \mathrm{kg}{ }^{-1}$. This estimate is larger than the calculated increase in equatorial Pacific deep water $\Delta\left[\mathrm{CO}_{3}^{2-}\right]$ during the Oi-1 glacial expansion in the earliest Oligocene $\left(\sim 54 \mu \mathrm{mol} \mathrm{kg}{ }^{-1}\right.$ at ODP Site 1218 , Lear and Rosenthal, 2006). The estimated change in bottom water $\Delta\left[\mathrm{CO}_{3}^{2-}\right]$ at Site 1218 is based on a $\mathrm{Li} / \mathrm{Ca}$ record also derived from $O$. umbonatus and a core top calibration from one site in the Norwegian Sea (Lear and Rosenthal, 2006), which gives a similar relationship to the core top calibration used here (Dawber and Tripati, 2012). Sediment accumulation at Site 1218 provides corroborating evidence for a large increase in $\Delta\left[\mathrm{CO}_{3}^{2-}\right]$ across $\mathrm{Oi}-1$, which resulted in a $1.2 \mathrm{~km}$ deepening of the calcite saturation horizon (CCD, Tripati et al., 2005). Independent evidence for a similarly large change in intermediate water $\Delta\left[\mathrm{CO}_{3}^{2-}\right]$ at Site 1209 during the late middle Eocene $(\sim 38.7-37.0 \mathrm{Ma})$ is more equivocal (Fig. 1). Records of weight percent calcium carbonate at Sites 1209 (Hancock and Dickens, 2005), 1218 and 1219 (Tripati et al., 2005; Lyle et al., 2005) support an increase in Pacific deep and intermediate water $\Delta\left[\mathrm{CO}_{3}^{2-}\right]$ between 40 and $37 \mathrm{Ma}$ and an $\sim 0.5 \mathrm{~km}$ deepening of the CCD (carbonaccumulation event 4 (CAE-4) of Lyle et al., 2005). In contrast, foraminifera dissolution indices at Site 1209 (Hancock and Dickens, 2005; Dawber and Tripati, 2011) suggest increasingly corrosive pore waters beginning at $\sim 40.5 \mathrm{Ma}$ to at least $38 \mathrm{Ma}$. The $O$. umbonatus $\delta^{13} \mathrm{C}$ record for Site 1209 also shows a small decrease $(0.3-0.4 \%$ ) during CAE4 , which may reflect a decrease in carbon isotope composition of pore waters as a result of organic carbon remineralization.

The discrepancies between the Site 1209, 1218 and 1219 weight percent $\mathrm{CaCO}_{3}$ records, the $\mathrm{CCD}$ reconstruction, the Site $1209 \mathrm{Sr} / \mathrm{Ca}$ and $\mathrm{Li} / \mathrm{Ca}$ estimates of $\Delta\left[\mathrm{CO}_{3}^{2-}\right]$ and the Site 1209 foraminifera dissolution indices during CAE-4 are somewhat perplexing. These trends could indicate a decoupling of the CCD and lysocline and/or bottom water and pore water $\Delta\left[\mathrm{CO}_{3}^{2-}\right]$ at Site 1209 or alternatively that bottom water $\Delta\left[\mathrm{CO}_{3}^{2-}\right]$ is not the dominant control on some or all of these records. During earlier carbonate accumulation events in the middle Eocene, foraminifera dissolution indices are consistent with the weight percent $\mathrm{CaCO}_{3}$ records for Site 1209, 1218 and 1219 (Fig. 1). The Site $1209 \mathrm{Sr} / \mathrm{Ca}$ record also exhibits small increases, equivalent to $\sim 20 \mu \mathrm{mol} \mathrm{kg}^{-1}$, during CAE-3 at $\sim 41.0 \mathrm{Ma}$, and CAE2 at $\sim 44.5 \mathrm{Ma}$. The $\mathrm{Mg} / \mathrm{Ca}$ record shows the opposite response to the $\mathrm{Sr} / \mathrm{Ca}$ record, the foraminifera dissolution indices and $\mathrm{CCD}$ reconstruction during CAE-4, CAE-3 and CAE-2, suggesting that $\Delta\left[\mathrm{CO}_{3}^{2-}\right]$ is not the dominant influence on $\mathrm{Mg} / \mathrm{Ca}$. During CAE-3 there is no change in the Site 1209 O. umbonatus $\delta^{13} \mathrm{C}$ and weight percent organic carbon records, or in the $O$. umbonatus $\delta^{13} \mathrm{C}$ record across CAE2. Although such comparisons provide a first-order assessment, we note that $O$. umbonatus $\delta^{13} \mathrm{C}$ and weight percent organic carbon are primarily influenced by different processes, e.g. $\mathrm{CaCO}_{3}: \mathrm{C}_{\text {organic }}$ rain rate, which in turn may influence bottom water and/or pore water $\Delta\left[\mathrm{CO}_{3}^{2-}\right]$.

\section{Comparison to the basinal CCD record}

Qualitatively, the $\mathrm{Sr} / \mathrm{Ca}$ - and $\mathrm{Li} / \mathrm{Ca}$-based estimates for the change in $\Delta\left[\mathrm{CO}_{3}^{2-}\right]$ at Site 1209 are consistent with the reconstruction of the Pacific CCD (Tripati et al., 2005) on million year timescales. However, quantitatively the $\mathrm{Sr} / \mathrm{Ca}-$ and $\mathrm{Li} / \mathrm{Ca}$-based estimates of $\Delta\left[\mathrm{CO}_{3}^{2-}\right]$ across CAE-4 are inconsistent both with each other and with the estimated change in the depth of the CCD, assuming a similar scaling to the Oi-1 glaciation (i.e. $1.2 \mathrm{~km}$ deepening of the $\mathrm{CCD}$ and an estimated change of $54 \mu \mathrm{mol} \mathrm{kg}{ }^{-1}$ in Pacific deepwater $\Delta\left[\mathrm{CO}_{3}^{2-}\right]$; Lear and Rosenthal, 2006). The thermal and carbonate saturation profiles of the equatorial Pacific during the Eocene are not well constrained; therefore, it is unclear whether large changes in deepwater $\Delta\left[\mathrm{CO}_{3}^{2-}\right]$, as implied by the substantial changes in the depth of the CCD, would propagate to intermediate water depths. Nonetheless, the discrepancies in the structure and amplitude of the $\mathrm{X} / \mathrm{Ca}$ records at Site 1209 indicate that either the sensitivity to $\Delta\left[\mathrm{CO}_{3}^{2-}\right]$ established from core tops is not appropriate for the Eocene or that secondary parameters contribute to, or may indeed be the dominant influence on, O. umbonatus X/Ca.

\section{Quantifying changes in $\Delta\left[\mathrm{CO}_{3}^{2-}\right]$ in the LGM-Holocene using single $\mathrm{X} / \mathrm{Ca}$ records}

$\mathrm{Yu}$ and Elderfield (2007) report changes in North Atlantic Ocean intermediate water (BOFS $17 \mathrm{~K}$ ) $\Delta\left[\mathrm{CO}_{3}^{2-}\right]$ of $20-$ $30 \mu \mathrm{mol} \mathrm{kg}{ }^{-1}$ between the Last Glacial Maximum (LGM) and the Holocene based on a record of Cibicidoides mundulus $\mathrm{B} / \mathrm{Ca}$. For comparison, $\mathrm{Sr} / \mathrm{Ca}$ data for the same core (from C. wuellerstorfi, Lear et al., 2003), when normalised to $O$. umbonatus using the species offsets of Lear et al. (2003) and converted into $\Delta\left[\mathrm{CO}_{3}^{2-}\right]$ using the core top calibration from Dawber and Tripati (2012), yield a LGM-Holocene change of $\sim 70 \mu \mathrm{mol} \mathrm{kg}^{-1}$. Although this comparison of LGM-Holocene $\Delta\left[\mathrm{CO}_{3}^{2-}\right]$ estimates may be overly simple and biased by inaccuracies in the species corrections, core top calibrations, and the analytical uncertainty associated with measurements on different instruments, it illustrates that there are also discrepancies between different $\mathrm{X} / \mathrm{Ca}$-based reconstructions of $\Delta\left[\mathrm{CO}_{3}^{2-}\right]$ during the Pleistocene. Thus it is clear that similar inconsistencies exist when examining $\mathrm{X} / \mathrm{Ca}$ records from much younger samples that span a shorter $\mathrm{du}-$ ration - i.e. when diagenetic artefacts can be excluded, and changes in seawater inventories of $\mathrm{Li}, \mathrm{B}, \mathrm{Mg}$, and $\mathrm{Sr}$ can be excluded. Therefore, discrepancies between the different $\mathrm{X} / \mathrm{Ca}-\Delta\left[\mathrm{CO}_{3}^{2-}\right]$ reconstructions likely indicate the influence of additional parameters on foraminiferal $\mathrm{X} / \mathrm{Ca}$ that are yet unquantified, and imply there is still an incomplete understanding of the controls on elemental incorporation into 
benthic foraminifera that hinders our ability to confidently quantify changes in saturation state using single $\mathrm{X} / \mathrm{Ca}$ reconstructions over timescales ranging from the early Cenozoic to LGM and Holocene.

\subsubsection{Temperature}

$\mathrm{Mg} / \mathrm{Ca}$ ratios in core top specimens of $O$. umbonatus exhibit a strong correlation with bottom water temperature (Lear et al., 2002, 2004; Rathmann et al., 2004; Healey et al., 2008), although the systematics of this relationship are poorly understood. A number of studies have used the $\mathrm{Mg} / \mathrm{Ca}$ ratio of $O$. umbonatus to reconstruct past temperature variations on the assumption that the sensitivity of $\mathrm{Mg} / \mathrm{Ca}$ to bottom water $\Delta\left[\mathrm{CO}_{3}^{2-}\right]$ and other parameters is minor/negligible (e.g. Lear et al., 2000; Billups and Schrag, 2003; Lear et al., 2004; Dutton et al., 2005; Tripati and Elderfield, 2005; Tripati et al., 2005; Sosdian and Rosenthal, 2009; Dawber and Tripati, 2011). Multiple linear regression of published core top $O$. umbonatus $\mathrm{Mg} / \mathrm{Ca}$ against bottom water temperature and $\Delta\left[\mathrm{CO}_{3}^{2-}\right]$ yields a more significant relationship than simple linear regression on either parameter (Table 2 , significance assessed by regression $r^{2}$-value, $p$-values of parameter coefficients and the Akaike information criterion). We consider several subsets of the combined $\mathrm{Mg} / \mathrm{Ca}$ data as uncorrected anthropogenic DIC data are not available for all localities, and some studies have questioned the reliability of some of the published $\mathrm{Mg} / \mathrm{Ca}$ data due to potential issues arising from contamination or diagenetic alteration (Marchitto et al., 2007). Regardless of the data subset used in the multiple linear regression, it is clear that small changes in temperature will drive measurable changes in $\mathrm{Mg} / \mathrm{Ca}$, and that in contrast, large changes in saturation state would need to be inferred in ordered to observe similar amplitude changes in $\mathrm{Mg} / \mathrm{Ca}$. The $\mathrm{Mg} / \mathrm{Ca}$ sensitivity to temperature is $\sim 0.103 \mathrm{mmol} \mathrm{mol}^{-1}{ }^{\circ} \mathrm{C}^{-1}$ and the sensitivity to $\Delta\left[\mathrm{CO}_{3}^{2-}\right]$ is $\sim 0.013 \mathrm{mmol} \mathrm{mol}^{-1} \mu \mathrm{mol}^{-1} \mathrm{~kg}^{-1}$ (Table 2). Multiple linear regression is not, however, an infallible test of the relative influence of temperature and $\Delta\left[\mathrm{CO}_{3}^{2-}\right]$ on $O$. umbonatus $\mathrm{Mg} / \mathrm{Ca}$ as these two parameters exhibit a high degree of covariation in the oceans leading to issues of spatial autocorrelation in the regression. A similar approach to that adopted by Yu and Elderfield (2008), which examines depth-dependent variations in benthic $\mathrm{Mg} / \mathrm{Ca}$ across the last Glacial Maximum-Holocene transition at a site with wellconstrained bottom water temperature and $\Delta\left[\mathrm{CO}_{3}^{2-}\right]$ histories, would provide a secondary assessment of the relative influence of these parameters. Nonetheless, the structure of the $\mathrm{Mg} / \mathrm{Ca}$ record for Site 1209 is consistently different to the $\mathrm{Li} / \mathrm{Ca}, \mathrm{B} / \mathrm{Ca}$ and $\mathrm{Sr} / \mathrm{Ca}$ records during the middle Eocene, further suggesting that it is temperature, rather than other environmental parameters, that is the dominant influence on $O$. umbonatus $\mathrm{Mg} / \mathrm{Ca}$.

Unfortunately, measurements of core top $O$. umbonatus $\mathrm{Li} / \mathrm{Ca}, \mathrm{B} / \mathrm{Ca}$ and $\mathrm{Sr} / \mathrm{Ca}$ that span a significant temperature range are not available, so it is not possible to rigorously assess the temperature influence on these element ratios. We note that a weak, negative relationship between $\mathrm{Li} / \mathrm{Ca}$ and temperature has been reported for several species of benthic and planktonic foraminifera (Hall and Chan, 2004; Marriott et al., 2004; Bryan and Marchitto, 2008; Lear et al., 2010). As an exercise, we assume that temperature is the primary influence on $O$. umbonatus $\mathrm{Mg} / \mathrm{Ca}$, and examine the apparent relationships with other X/Ca. Qualitatively, the trends in the B/Ca record at Site 1209 on timescales less than a million years display no similarity to the trends in the $\mathrm{Mg} / \mathrm{Ca}$ record. On the same timescale $(<1 \mathrm{Myr})$, there is no clear correlation between the trends in $\mathrm{Sr} / \mathrm{Ca}$ and $\mathrm{Mg} / \mathrm{Ca}$, with the possible exception of 41-40 Ma when the records appear to be negatively correlated. Qualitatively, the $O$. umbonatus $\mathrm{Li} / \mathrm{Ca}$ record does appear to exhibit a weak positive correlation with the $\mathrm{Mg} / \mathrm{Ca}$ record. We note that observation is opposite to what has been observed for other benthic and planktonic species (Hall and Chan, 2004; Marriott et al., 2004; Bryan and Marchitto, 2008; Lear et al., 2010) and is not really substantiated quantitatively when $\mathrm{Li} / \mathrm{Ca}$ data from Site 1209 are cross-plotted against $\mathrm{Mg} / \mathrm{Ca}$ data (Fig. 2). X/Ca data are grouped into discrete time periods with durations less than the residence time of $\mathrm{X}$ and $\mathrm{Ca}$ in the ocean and plotted against $\mathrm{Mg} / \mathrm{Ca}$ (refer to different coloured data subsets in Fig. 2). The middle Eocene $\mathrm{Sr} / \mathrm{Ca}, \mathrm{Li} / \mathrm{Ca}$ or B/Ca data from Site 1209 do not display any consistent relationships with the $\mathrm{Mg} / \mathrm{Ca}$ data.

A number of studies have proposed the use of multiple $\mathrm{X} / \mathrm{Ca}$ to better constrain variations in seawater temperature and $\Delta\left[\mathrm{CO}_{3}^{2-}\right]$ (e.g. Bryan and Marchitto, 2008; Lear et al., 2010). Different methods have been used to refine the sensitivity of $\mathrm{Mg} / \mathrm{Ca}$ and $\mathrm{Li} / \mathrm{Ca}$ to temperature and/or $\Delta\left[\mathrm{CO}_{3}^{2-}\right]$, (1) using the ratio of $\mathrm{Mg} / \mathrm{Li}$, which is based on the assumption that the different responses of benthic foraminiferal $\mathrm{Mg} / \mathrm{Ca}$ and $\mathrm{Li} / \mathrm{Ca}$ to environmental parameters (temperature and $\left.\Delta\left[\mathrm{CO}_{3}^{2-}\right]\right)$ can be used to correct the other ratio (e.g. Bryan and Marchitto, 2008) and (2) by independently establishing the sensitivity of benthic foraminiferal $\mathrm{Mg} / \mathrm{Ca}$ and $\mathrm{Li} / \mathrm{Ca}$ to temperature and $\Delta\left[\mathrm{CO}_{3}^{2-}\right]$ and using paired analyses to derive estimates of both parameters (e.g. Lear et al., 2010). Whilst both methods demonstrate good potential for deriving more accurate estimates of multiple environmental parameters and warrant further investigation, we have not applied these relationships/methodologies herein because a number of observations based on the Site 1209 downcore X/Ca records and the O. umbonatus core top dataset (Dawber and Tripati, 2012) suggest that they are not appropriate in their current form. Firstly, the paired $\mathrm{Mg} / \mathrm{Ca}$ and $\mathrm{Li} / \mathrm{Ca}$ equations of Lear et al. (2010) are based on the assumption that the sensitivity of $O$. umbonatus $\mathrm{Mg} / \mathrm{Ca}$ to bottom water $\Delta\left[\mathrm{CO}_{3}^{2-}\right]$ is the same as that reported by Elderfield et al. (2006) for other epifaunal benthic species $\left(0.0086 \pm 0.0006 \mathrm{mmol} \mathrm{mol}^{-1} \mu \mathrm{mol}^{-1} \mathrm{~kg}^{-1}\right)$. However, a recent study of the sensitivity of $O$. umbonatus 
Table 1. Linear least square regression models fitted through $\mathrm{X} / \mathrm{Ca}$ and $\Delta\left[\mathrm{CO}_{3}^{2-}\right]$ data.

\begin{tabular}{|c|c|c|c|c|c|c|c|c|c|c|c|c|}
\hline \multirow[b]{2}{*}{$\mathrm{X} / \mathrm{Ca}$} & \multirow[b]{2}{*}{ Dataset used } & \multirow[b]{2}{*}{$T$ range $\left({ }^{\circ} \mathrm{C}\right)$} & \multirow{2}{*}{$\begin{array}{r}\Delta\left[\mathrm{CO}_{3}^{2-}\right] \text { range } \\
\left(\mu \mathrm{mol} \mathrm{kg}{ }^{-1}\right)\end{array}$} & \multirow[b]{2}{*}{$n$} & \multicolumn{4}{|c|}{$\Delta\left[\mathrm{CO}_{3}^{2-}\right]$ not corrected for anthropogenic DIC } & \multicolumn{4}{|c|}{$\Delta\left[\mathrm{CO}_{3}^{2-}\right]$ corrected for anthropogenic DIC } \\
\hline & & & & & Slope* & Intercept & $R^{2}$ & $\mathrm{p}$-value & Slope* & Intercept & $R^{2}$ & $\mathrm{p}$-value \\
\hline $\mathrm{B} / \mathrm{Ca}$ & $\begin{array}{l}\text { Dawber and } \\
\text { Tripati (2012) }\end{array}$ & 1.1 to 3.6 & -23 to 44 & 37 & $0.433 \pm 0.053$ & $29.7 \pm 1.1$ & 0.65 & $1.5 \times 10^{-9}$ & $0.369 \pm 0.045$ & $29.9 \pm 1.1$ & 0.66 & $1.3 \times 10^{-9}$ \\
\hline \multirow[t]{3}{*}{$\mathrm{Li} / \mathrm{Ca}$} & All datasets & -0.8 to 3.6 & -23 to 45 & 44 & $0.0526 \pm 0.0084$ & $15.53 \pm 0.19$ & 0.46 & $1.1 \times 10^{-7}$ & & & & \\
\hline & $\begin{array}{l}\text { Dawber and } \\
\text { Tripati (2012) }\end{array}$ & 1.1 to 3.6 & -23 to 44 & 37 & $0.0561 \pm 0.0105$ & $15.56 \pm 0.22$ & 0.45 & $6.2 \times 10^{-6}$ & $0.0466 \pm 0.0091$ & $15.60 \pm 0.22$ & 0.43 & $1.2 \times 10^{-5}$ \\
\hline & Lear et al. (2006) & -0.8 to 0.6 & 6 to 45 & 9 & 0.0515 & 15.3 & 0.69 & 0.00149 & & & & \\
\hline $\mathrm{Sr} / \mathrm{Ca}$ & $\begin{array}{l}\text { Dawber and } \\
\text { Tripati (2012) }\end{array}$ & 1.1 to 3.6 & -23 to 44 & 37 & $0.00241 \pm 0.0004$ & $0.8756 \pm 0.0074$ & 0.57 & $7.4 \times 10^{-8}$ & $0.00207 \pm 0.0003$ & $0.8764 \pm 0.0072$ & 0.58 & $5.2 \times 10^{-8}$ \\
\hline \multirow[t]{7}{*}{$\mathrm{Mg} / \mathrm{Ca}$} & $\begin{array}{l}\text { All datasets } \\
\text { (except Rathmann } \\
\text { and Kuhnert, } \\
\text { 2007) }\end{array}$ & -0.9 to 10.5 & 25 to 70 & 83 & $0.0164 \pm 0.0016$ & $1.381 \pm 0.0366$ & 0.59 & $1.7 \times 10^{-9}$ & $0.0102 \pm 0.0014$ & $1.413 \pm 0.05$ & 0.41 & $9.6 \times 10^{-11}$ \\
\hline & $\begin{array}{l}\text { Same but multiple } \\
\text { linear regression } \\
\text { (Table 2) }\end{array}$ & -0.9 to 10.5 & 25 to 70 & 83 & $0.017 \pm 0.002$ & $1.199 \pm 0.055$ & $1.472 \pm 0.043$ & $1.5 \times 10^{-14}$ & $0.0083 \pm 0.001$ & $1.215 \pm 0.054$ & 0.56 & $3.2 \times 10^{-9}$ \\
\hline & $\begin{array}{l}\text { Dawber and } \\
\text { Tripati (2012) }\end{array}$ & 1.1 to 3.6 & -23 to 44 & 37 & $0.0122 \pm 0.0016$ & $1.400 \pm 0.034$ & 0.61 & $1.8 \times 10^{-8}$ & $0.00992 \pm 0.0015$ & $1.412 \pm 0.036$ & 0.56 & $1.6 \times 10^{-7}$ \\
\hline & $\begin{array}{l}\text { Healey et } \\
\text { al. (2008) }\end{array}$ & 1.2 to 4 & -3 to 39 & 24 & $0.0227 \pm 0.0049$ & $1.355 \pm 0.105$ & 0.49 & $1.3 \times 10^{-4}$ & & & & \\
\hline & $\begin{array}{l}\text { Elderfield et } \\
\text { al. (2006) }\end{array}$ & -0.9 to -0.8 & 6 to 36 & 6 & & & & & $0.0024 \pm 0.0019$ & $1.422 \pm 0.048$ & 0.27 & 0.298 \\
\hline & Lear et al. (2002) & 0.8 to 10.5 & -22 to 0 & 16 & $0.0190 \pm 0.0032$ & $1.382 \pm 0.087$ & 0.76 & $1.3 \times 10^{-5}$ & & & & \\
\hline & $\begin{array}{l}\text { Rathmann and } \\
\text { Kuhnert (2008) }\end{array}$ & 1.6 to 10.4 & -25 to 21 & 6 & $-0.0092 \pm 0.0119$ & $2.137 \pm 0.217$ & 0.13 & & & & & \\
\hline
\end{tabular}

* $\mathrm{mmol} \mathrm{mol}^{-1} \mu \mathrm{mol}^{-1} \mathrm{~kg}^{-1}$ except for B/Ca and $\mathrm{Li} / \mathrm{Ca}: \mu \mathrm{mol} \mathrm{mol}{ }^{-1} \mu \mathrm{mol} \mathrm{kg}^{-1}$.

Table 2. Linear least square regression models fitted through $\mathrm{Mg} / \mathrm{Ca}$, temperature and $\Delta\left[\mathrm{CO}_{3}^{2-}\right]$ data.

\begin{tabular}{|c|c|c|c|c|c|c|c|c|c|c|}
\hline $\begin{array}{l}\text { Data } \\
\text { set }\end{array}$ & $\mathrm{N}$ & Model & A & B & $\mathrm{C}$ & $R^{2}$ & AIC & $\mathrm{p}$-value & $\begin{array}{r}\text { Residual } \\
\text { standard } \\
\text { error }\end{array}$ & $\begin{array}{r}{ }^{*} \text { Ratio } \\
\text { B/C }\end{array}$ \\
\hline \multirow[t]{4}{*}{1} & 83 & $\mathrm{Mg} / \mathrm{Ca}=1$ (null) & & & & & 99.7 & & & \\
\hline & & $\mathrm{Mg} / \mathrm{Ca}=\mathrm{A}+\mathrm{B}^{*} \mathrm{BWT}$ & $1.360 \pm 0.071$ & $0.161 \pm 0.026$ & & 0.32 & 69.1 & A: $2.0 \times 10^{-16}$ B: $1.9 \times 10^{-8}$ & 0.36 & \\
\hline & & $\mathrm{Mg} / \mathrm{Ca}=\mathrm{A}+\mathrm{C}^{*} \Delta\left[\mathrm{CO}_{3}^{2-}\right]$ & $1.472 \pm 0.043$ & & $0.017 \pm 0.002$ & 0.51 & 40.7 & A: $2.0 \times 10^{-16} \mathrm{C}: 1.5 \times 10^{-14}$ & 0.30 & \\
\hline & & $\mathrm{Mg} / \mathrm{Ca}=\mathrm{A}+\mathrm{B}^{*} \mathrm{BWT}+\mathrm{C}^{*} \Delta\left[\mathrm{CO}_{3}^{2-}\right]$ & $1.355 \pm 0.057$ & $0.073 \pm 0.025$ & $0.014 \pm 0.002$ & 0.56 & 34.1 & A: $2.0 \times 10^{-16}$ B: $0.00402 \mathrm{C}: 2.6 \times 10^{-9}$ & 0.29 & 5.2 \\
\hline \multirow[t]{4}{*}{2} & 79 & $\mathrm{Mg} / \mathrm{Ca}=1$ (null) & & & & & 66.2 & & & \\
\hline & & $\mathrm{Mg} / \mathrm{Ca}=\mathrm{A}+\mathrm{B}^{*} \mathrm{BWT}$ & $1.329 \pm 0.077$ & $0.169 \pm 0.033$ & & 0.24 & 45.3 & $\mathrm{~A}:<2 \times 10^{-16}$ B: $2.5 \times 10^{-6}$ & 0.31 & \\
\hline & & $\mathrm{Mg} / \mathrm{Ca}=\mathrm{A}+\mathrm{C}^{*} \Delta\left[\mathrm{CO}_{3}^{2-}\right]$ & $1.486 \pm 0.039$ & & $0.015 \pm 0.002$ & 0.43 & 22.8 & $\mathrm{~A}:<2 \times 10^{-16} \mathrm{C}: 3.2 \times 10^{-11}$ & 0.27 & \\
\hline & & $\mathrm{Mg} / \mathrm{Ca}=\mathrm{A}+\mathrm{B}^{*} \mathrm{BWT}+\mathrm{C}^{*} \Delta\left[\mathrm{CO}_{3}^{2-}\right]$ & $1.289 \pm 0.061$ & $0.110 \pm 0.028$ & $0.012 \pm 0.002$ & 0.52 & 9.9 & A: $<2 \times 10^{-16}$ B: 0.000160 C: $2.2 \times 10^{-9}$ & 0.25 & 9.2 \\
\hline \multirow[t]{4}{*}{3} & 77 & $\mathrm{Mg} / \mathrm{Ca}=1$ (null) & & & & & 104.9 & & & \\
\hline & & $\mathrm{Mg} / \mathrm{Ca}=\mathrm{A}+\mathrm{B}^{*} \mathrm{BWT}$ & $1.247 \pm 0.090$ & $0.200 \pm 0.032$ & & 0.34 & 65.9 & $\mathrm{~A}:<2 \times 10^{-16}$ B: $2.0 \times 10^{-8}$ & 0.36 & \\
\hline & & $\mathrm{Mg} / \mathrm{Ca}=\mathrm{A}+\mathrm{C}^{*} \Delta\left[\mathrm{CO}_{3}^{2-}\right]$ & $1.486 \pm 0.042$ & & $0.018 \pm 0.002$ & 0.57 & 32.0 & $\mathrm{~A}:<2 \times 10^{-16} \mathrm{C}: 1.1 \times 10^{-15}$ & 0.29 & \\
\hline & & $\mathrm{Mg} / \mathrm{Ca}=\mathrm{A}+\mathrm{B}^{*} \mathrm{BWT}+\mathrm{C}^{*} \Delta\left[\mathrm{CO}_{3}^{2-}\right]$ & $1.446 \pm 0.078$ & $0.023 \pm 0.037$ & $0.017 \pm 0.003$ & 0.57 & 33.6 & $\mathrm{~A}:<2 \times 10^{-16}$ B: $0.547 \mathrm{C}: 1.1 \times 10^{-8}$ & 0.29 & 1.4 \\
\hline \multirow[t]{4}{*}{4} & 73 & $\mathrm{Mg} / \mathrm{Ca}=1$ (null) & & & & & 65.2 & & & \\
\hline & & $\mathrm{Mg} / \mathrm{Ca}=\mathrm{A}+\mathrm{B}^{*} \mathrm{BWT}$ & $0.967 \pm 0.119$ & $0.317 \pm 0.050$ & & 0.35 & 34.2 & A: $1.1 \times 10^{-11}$ B: $1.7 \times 10^{-8}$ & 0.30 & \\
\hline & & $\mathrm{Mg} / \mathrm{Ca}=\mathrm{A}+\mathrm{C}^{*} \Delta\left[\mathrm{CO}_{3}^{2-}\right]$ & $1.495 \pm 0.038$ & & $0.016 \pm 0.002$ & 0.50 & 14.9 & $\mathrm{~A}:<2 \times 10^{-16} \mathrm{C}: 1.18 \times 10^{-12}$ & 0.2608 & \\
\hline & & $\mathrm{Mg} / \mathrm{Ca}=\mathrm{A}+\mathrm{B}^{*} \mathrm{BWT}+\mathrm{C}^{*} \Delta\left[\mathrm{CO}_{3}^{2-}\right]$ & $1.296 \pm 0.122$ & $0.103 \pm 0.061$ & $0.013 \pm 0.003$ & 0.52 & 13.9 & A: $3.5 \times 10^{-16}$ B: $0.0924 . C: 4.1 \times 10^{-6}$ & 0.26 & 7.9 \\
\hline
\end{tabular}

Datasets: 1 - All data except Rathmann and Kuhnert (2008). 2 - All data except Rathmann and Kuhnert (2008) and Little Bahama Bank data from Lear et al. (2002). 3 - All data except Rathmann and Kuhnert (2008) and Norwegian Sea data from Elderfield et al. (2006). 4 - All data except Rathmann and Kuhnert (2008), Little Bahama Bank data from Lear et al. (2002) and Norwegian Sea data from Elderfield et al. (2006). * Ratio BWT: $\Delta\left[\mathrm{CO}_{3}^{2-}\right]$ coefficients (per unit $\mathrm{Mg} / \mathrm{Ca}$ change).

$\mathrm{Mg} / \mathrm{Ca}$ to bottom water $\Delta\left[\mathrm{CO}_{3}^{2-}\right]$ provides a different estimate $\left(0.017 \mathrm{mmol} \mathrm{mol}^{-1} \mu \mathrm{mol}^{-1} \mathrm{~kg}^{-1}\right.$, Dawber and Tripati, 2012), which is based on a larger dataset for this specific species. Secondly, the methodology of using $\mathrm{Mg} / \mathrm{Li}$ to provide a more accurate proxy estimate of temperature by correcting for the suppression of $\mathrm{Mg} / \mathrm{Ca}$ at high $\Delta\left[\mathrm{CO}_{3}^{2-}\right]$ is based on observations that some benthic species exhibit a negative correlation between $\mathrm{Li} / \mathrm{Ca}$ and temperature and $\Delta\left[\mathrm{CO}_{3}^{2-}\right]$, in contrast to the positive relationships observed for benthic $\mathrm{Mg} / \mathrm{Ca}$ (Bryan and Marchitto, 2008). Lear and Rosenthal (2006) and Dawber and Tripati (2012) both report a positive correlation between $O$. umbonatus $\mathrm{Li} / \mathrm{Ca}$ and bottom water $\Delta\left[\mathrm{CO}_{3}^{2-}\right]$. In addition, the comparison of the downcore $\mathrm{Li} / \mathrm{Ca}$ and $\mathrm{Mg} / \mathrm{Ca}$ records at Site 1209 shows a qualitative weak positive correlation. These observations suggest that the factors influencing $O$. umbonatus 

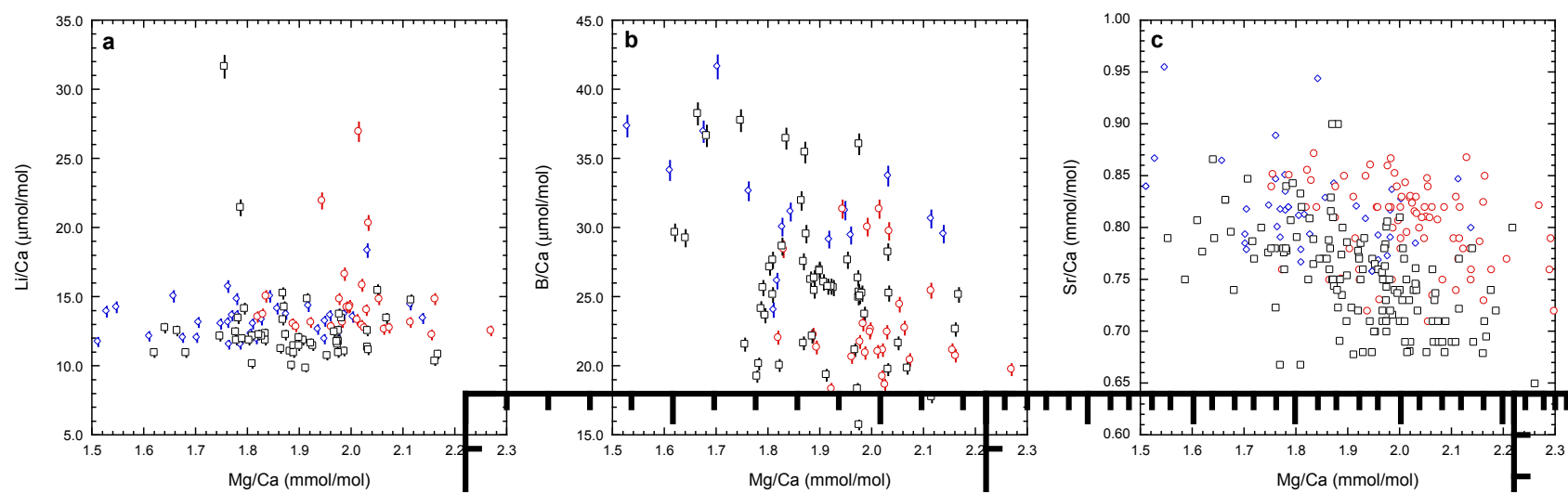

Fig. 2. Cross-plots of contemporaneous $O$. umbonatus $\mathrm{Li} / \mathrm{Ca}, \mathrm{B} / \mathrm{Ca}$ and $\mathrm{Sr} / \mathrm{Ca}$ data against $\mathrm{Mg} / \mathrm{Ca}$. The different colour and symbol combinations denote different intervals of the record. The intervals represent $<10^{6} \mathrm{yr}(\mathbf{b})$ and (c) and $5.7 \times 10^{5} \mathrm{yr}(\mathbf{a})$, which do not exceed the residence time of the $\mathrm{X}$ or $\mathrm{Ca}$ ions in the ocean. Error bars for $\mathrm{Li} / \mathrm{Ca}$ and $\mathrm{B} / \mathrm{Ca}$ measurements denote analytical precision, estimated to be $\sim 2 \%$ based on replicate foraminiferal analyses. The uncertainty associated with $\mathrm{Sr} / \mathrm{Ca}$ precision is smaller than the size of the data symbol.

$\mathrm{X} / \mathrm{Ca}$ may be different to other benthic species. Dawber and Tripati (2012) reached a similar conclusion when examining $O$. umbonatus core top $\mathrm{X} / \mathrm{Ca}$ with respect to the Rayleigh fractionation biomineralisation model. Without precise knowledge of the mechanistic controls on $\mathrm{Mg} / \mathrm{Ca}$ and $\mathrm{Li} / \mathrm{Ca}$ in $O$. umbonatus, or a similar study to that of Bryan and Marchitto (2008) on core top samples that span a large temperature and $\Delta\left[\mathrm{CO}_{3}^{2-}\right]$ range, it is not clear what exactly $\mathrm{Mg} / \mathrm{Li}$ records reflect in $O$. umbonatus.

\subsubsection{Seawater composition}

Foraminifera are thought to calcify through the vacuolization of seawater (Erez et al., 1994; Erez, 2003), so foraminifera $\mathrm{X} / \mathrm{Ca}$ may reflect changes in the magnitude and/or $\mathrm{X} / \mathrm{Ca}$ of cation fluxes into and out of the ocean. The residence time of $\mathrm{Li}, \mathrm{B}, \mathrm{Sr}, \mathrm{Mg}$ and $\mathrm{Ca}$ in the ocean varies $\left(\sim 3 \times 10^{6}, \sim 10^{7}\right.$, $\sim 5 \times 10^{6}, \sim 13 \times 10^{7}$, and $\sim 10^{6}$ yr respectively; Broecker and Peng, 1982), so it is likely that the element ratio composition of seawater was different to modern times during the middle Eocene and that individual element compositions may have changed at different times throughout the duration of the Site 1209 records. Sequence stratigraphic and geochemical proxy reconstructions support highly variable sea level during the middle Eocene (Browning et al., 1996; Miller et al., 2005; Tripati et al., 2005; Dawber and Tripati, 2011; Dawber et al., 2011). An increase in the $\mathrm{Ca}^{2+}$ flux from continental weathering when unaccompanied by carbonate compensation is a mechanism of lowering seawater $\mathrm{X} / \mathrm{Ca}$, and has been proposed as one way to account for the apparent increase in seawater $\left[\mathrm{Ca}^{2+}\right]$ during the middle Miocene glacial expansion (Griffith et al., 2008). During the Neogene the magnitude of seawater $\left[\mathrm{Ca}^{2+}\right]$ variations on timescales of 2-4 Myr is 20\% (Fantle and DePaolo, 2005), which is similar to the long-term variability in the middle Eocene $\mathrm{Sr} / \mathrm{Ca}$ and $\mathrm{Mg} / \mathrm{Ca}$ records at Site 1209 . However, it is difficult to conceive that seawater $\left[\mathrm{Ca}^{2+}\right]$ could be decoupled over million year periods from calcite compensation. Griffith et al. (2008) suggest that changes in the rate of dolomitization and/or the $\mathrm{Ca}^{2+}: \mathrm{HCO}_{3}^{-}$of riverine inputs are possible processes to decouple the $\mathrm{Ca}$ and $\mathrm{C}$ cycle, but additional work is required to evaluate these hypotheses. Shortterm $(<1 \mathrm{Myr})$ variations in the $\mathrm{X} / \mathrm{Ca}$ at Site 1209 , if solely due to changes in seawater $\left[\mathrm{Ca}^{2+}\right]$, would require extremely large and unrealistic changes over a geologically rapid time $\left(\sim 15 \%\right.$ in $\left[\mathrm{Ca}^{2+}\right]$ in $\left.<400 \mathrm{kyr}\right)$.

The release of $\mathrm{Sr}$ into the ocean via the erosion and/or recrystallisation of continental shelf aragonite may be an important control on seawater $\mathrm{Sr} / \mathrm{Ca}$ over a range of timescales, and is hypothesized to drive Pleistocene glacial-interglacial variations of up to $\sim 12 \%$ (Stoll and Schrag, 1998; Stoll et al., 1999). Switching the locus of carbonate deposition between the shelf and deep sea may amplify changes in seawater $\mathrm{Sr} / \mathrm{Ca}$ since most aragonite calcifying species live on the continental shelf (Martin et al., 1999). The effect of aragonite weathering fluxes on seawater $\mathrm{Li}$ and $\mathrm{B}$ concentrations is not well constrained, because partition coefficients for biogenic aragonite species are largely undetermined.

During parts of the middle Eocene, the Site $1209 \mathrm{~B} / \mathrm{Ca}$ record is positively correlated with the seawater $\delta^{18} \mathrm{O}$ reconstruction for this site (Fig. 3, Dawber and Tripati, 2011). A notable exception is between $\sim 38.7$ and 38 Ma when seawater $\delta^{18} \mathrm{O}$ decreases, but $\mathrm{B} / \mathrm{Ca}$ increases (Fig. 3). In contrast, the $O$. umbonatus $\mathrm{Sr} / \mathrm{Ca}$ and $\mathrm{Li} / \mathrm{Ca}$ records are negatively correlated with seawater $\delta^{18} \mathrm{O}$ throughout the middle Eocene (Fig. 3). Between 41.0 and $40.5 \mathrm{Ma}, \mathrm{Li} / \mathrm{Ca}$ records appear to be decoupled from $\mathrm{Sr} / \mathrm{Ca}$ and seawater $\delta^{18} \mathrm{O}$, although the significance of this trend is unclear as it is supported by only a few data points. $\mathrm{Sr} / \mathrm{Ca}$ values of $O$. umbonatus decrease by $\sim 21 \%$ across the $\sim 1.1 \%$ o positive shift in seawater $\delta^{18} \mathrm{O}$ commencing at $\sim 41 \mathrm{Ma}$, which is interpreted as a major 


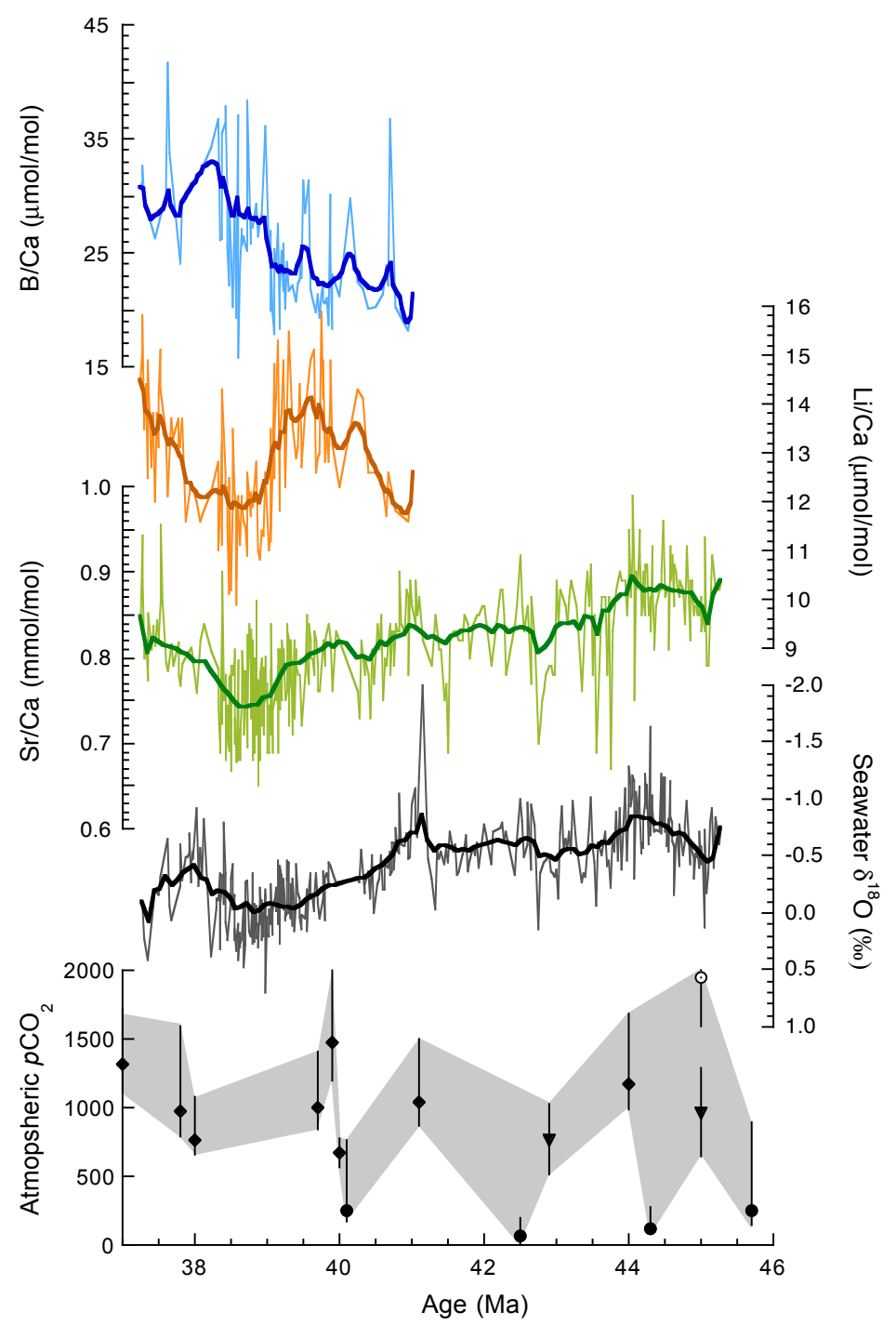

Fig. 3. Comparison of the downcore $O$. umbonatus X/Ca records with the seawater $\delta^{18} \mathrm{O}$ reconstruction from ODP Site 1209 (Dawber and Tripati, 2011). Shown for reference are estimates of atmospheric $p \mathrm{CO}_{2}$ based on alkenones (diamonds, Pagani et al., 2005; Freeman and Hayes, 1992); boron isotopes in carbonates (circles, Demicco et al., 2003); stomatal indices (inverted triangle, McElwain, 1998; Kurschner et al., 2001); and paleosol carbon isotopes (open circle with dot, Ekart et al., 1999).

episode of glacial expansion associated with a glacioeustatic lowering (Dawber and Tripati, 2011). If aragonite weathering was primarily responsible for seawater $\mathrm{Sr} / \mathrm{Ca}$ variations, the O. umbonatus $\mathrm{Sr} / \mathrm{Ca}$ record should be positively correlated with the seawater $\delta^{18} \mathrm{O}$ reconstruction. Our observations suggest that glacially mediated variations in the continental and shelf flux of $\mathrm{Sr}$ to the ocean are not the primary influence on O. umbonatus $\mathrm{Sr} / \mathrm{Ca}$. $\mathrm{Li}$ and B partition coefficients for biogenic shelf aragonite are needed to evaluate this effect on $\mathrm{Li} / \mathrm{Ca}$ and $\mathrm{B} / \mathrm{Ca}$ ratios in $O$. umbonatus.

A number of proxy-based studies estimate variations in seawater Sr/Ca during the Eocene (e.g. Lear et al., 2003; Tripati et al., 2009; Coggon et al., 2010; Balter et al., 2011). There are significant discrepancies in both the magnitude and direction of change in these reconstructions. For example, on longer timescales the Tripati et al. (2009) and Coggon et al. (2010) reconstructions exhibit opposing trends. The inconsistency of these reconstructions illustrates that there is significant uncertainty associated with published estimates of seawater $\mathrm{Sr} / \mathrm{Ca}$. Nonetheless, we note that the approximately $2 \mathrm{~mol} \mathrm{~mol}^{-1}$ increase in seawater $\mathrm{Sr} / \mathrm{Ca}$ observed in the $\mathrm{Cog}$ gon et al. (2010) reconstruction during the middle Eocene is inconsistent with the gradual decline in $O$. umbonatus $\mathrm{Sr} / \mathrm{Ca}$ at Site 1209. For other reconstructions, the paucity of data during the middle Eocene (Balter et al., 2011) and the benthic foraminifera data source (Lear et al., 2003) mean that comparisons with our benthic foraminifera $\mathrm{Sr} / \mathrm{Ca}$ are inappropriate. 
Several proxy data- and model-based studies have shown that seawater $\mathrm{Mg} / \mathrm{Ca}$ composition may have varied by $<$ $0.5 \mathrm{~mol} \mathrm{~mol}^{-1}$ during the middle Eocene (Wilkinson and Algeo, 1989; Lowenstein et al., 2001; Horita et al., 2002; Coggon et al., 2010). As discussed by Dawber and Tripati (2011), the changes in seawater $\mathrm{Mg} / \mathrm{Ca}$ on million year timescales during the middle Eocene are of a similar magnitude to that required to reconcile the benthic $\mathrm{Mg} / \mathrm{Ca}$ with the $3^{\circ} \mathrm{C}$ cooling implied by the benthic $\delta^{18} \mathrm{O}$ record at ODP Site 1209. However, there are several scenarios compatible with published seawater reconstructions that have notable differences in the timing and rate of change of seawater $\mathrm{Mg} / \mathrm{Ca}$. Without a consensus regarding middle Eocene seawater $\mathrm{Mg} / \mathrm{Ca}$ estimates, it is not possible to attribute a precise component of the O. umbonatus $\mathrm{Mg} / \mathrm{Ca}$ record from Site 1209 to a change in seawater composition. Given the long residence time of $\mathrm{Mg}^{2+}$ and $\mathrm{Ca}^{2+}$ in the oceans, it is unlikely that $O$. umbonatus $\mathrm{Mg} / \mathrm{Ca}$ variations on timescales of less than a million years are driven by seawater composition.

\subsubsection{Post-depositional alteration}

Foraminifera $\mathrm{X} / \mathrm{Ca}$ may be influenced by post-depositional dissolution and/or recrystallisation if the element partition coefficients are notably different for inorganic and biogenic carbonates. At present there is little consensus within the community as to how the magnitude of these effects can be assessed in a consistent manner at a single site or between sites. The planktonic fragmentation and benthic abundance proxies for post-depositional at Site 1209 display no first-order correlation with the $O$. umbonatus $\mathrm{X} / \mathrm{Ca}$ records (Fig. 1). For example, the increasing degree of fragmentation observed in the upper part of the core (ca. 40.5$38 \mathrm{Ma}$ ) does not correlate with a systematic and prolonged decrease in $O$. umbonatus element ratios (Fig. 1) In the absence of foraminiferal dissolution experiments at the pressure and temperature conditions of the deep-ocean, there is no way to equate observations of fragmentation quantitatively to changes in $\mathrm{X} / \mathrm{Ca}$. Scanning electron microscopy can be used to examine the surface and cross-sectional structure of foraminifera tests and evaluate possible diagenetic alteration through changes in crystal shape and size. However, this approach has many challenges, as it is unclear whether diagenetic alteration always results in a change in crystal properties and whether the secondary crystals represent a pure inorganic end-member composition. Even if such properties could be established, it is not clear how many specimens need to be examined in order to get a statistically representative assessment for a single species at a specific location. To better assess the role of post-depositional alteration on benthic foraminiferal $\mathrm{X} / \mathrm{Ca}$, comprehensive dissolution studies are required.

\subsubsection{Pore water chemistry}

O. umbonatus is an infaunal species, inhabiting the upper few centimeters of the sediment column (Corliss, 1985; Rathburn and Corliss, 1994). As a result of pore-water reactions, including the oxidation of organic matter, redox changes and acid neutralization, ambient pore water $\Delta\left[\mathrm{CO}_{3}^{2-}\right]$ may differ from bottom water $\Delta\left[\mathrm{CO}_{3}^{2-}\right]$ (Emerson and Bender, 1981; Archer et al., 1989; Archer 1991; Martin and Sayles, 1996). In scenarios where pore water $\Delta\left[\mathrm{CO}_{3}^{2-}\right]$ is less than bottom water $\Delta\left[\mathrm{CO}_{3}^{2-}\right]$, for example in areas with high sediment dissolution, the reported relationships between bottom water $\Delta\left[\mathrm{CO}_{3}^{2-}\right]$ and infaunal benthic X/Ca derived from core top data may underestimate the true sensitivity. Additional sources of uncertainty for the reported relationships between infaunal benthic foraminifera $\mathrm{X} / \mathrm{Ca}$ and bottom water $\Delta\left[\mathrm{CO}_{3}^{2-}\right]$ include the migration of foraminifera throughout the upper sediment column in response to environmental and food factors (Gross, 2000). However these factors will be difficult to quantify and will differ on a location basis.

We hypothesize that shifts in the speciation of dissolved inorganic boron species in pore waters in response to dissolution and neutralization reactions could also potentially introduce a significant bias in infaunal benthic foraminifera B/Ca-bottom water $\Delta\left[\mathrm{CO}_{3}^{2-}\right]$ relationships (Dawber and Tripati, 2012). The apparent lower sensitivity of core top calibrations derived for infaunal taxa $(O$. umbonatus and Uvigerina) relative to epifaunal species (Yu and Elderfield, 2007; Rae et al., 2011; Dawber and Tripati, 2012) are consistent with our hypothesis. We note that the relationship between o. umbonatus $\mathrm{B} / \mathrm{Ca}$ and bottom water $\Delta\left[\mathrm{CO}_{3}^{2-}\right]$ presented by Dawber and Tripati (2012) shows a coherent trend, possibly demonstrating that the processes discussed above do not introduce significant scatter within datasets for a single species.

\subsection{Estimates of $\Delta\left[\mathrm{CO}_{3}^{2-}\right]$ and temperature based on multi-element ratios}

The comparisons of the Site 1209 middle Eocene X/Ca records with each other, independent carbon cycle proxies and a seawater $\delta^{18} \mathrm{O}$ reconstruction indicate that element ratios in $O$. umbonatus are not controlled solely by bottom water $\Delta\left[\mathrm{CO}_{3}^{2-}\right]$. Recently, Gaetani and Cohen (2006) and Gaetani et al. (2011) introduced an application of the global minimization technique to solve variations in multiple parameters based on multi-element ratios in corals. Global minimization of multi-element ratio data in foraminifera is potentially a powerful paleoproxy tool for investigating the relative sensitivity of $\mathrm{X} / \mathrm{Ca}$ to several environmental parameters and a means of estimating downcore variations in these parameters. As an exercise, we assume that $\mathrm{Li} / \mathrm{Ca}, \mathrm{B} / \mathrm{Ca}, \mathrm{Mg} / \mathrm{Ca}$ and $\mathrm{Sr} / \mathrm{Ca}$ in $O$. umbonatus can be defined by multiple linear functions of both bottom water $\Delta\left[\mathrm{CO}_{3}^{2-}\right]$ and temperature. By iteratively changing initial estimates of bottom water 


\section{Solution 1:}

$\mathrm{Li} / \mathrm{Ca}=1.32 \times 10^{-8 *} \mathrm{Temp}+0.51^{*} \Delta\left[\mathrm{CO}_{3}{ }^{2-}\right]+9.68 \times 10^{-7}$
$\mathrm{~B} / \mathrm{Ca}=9.13 \times 10^{-9 *} \mathrm{Temp}+0.14^{*} \Delta\left[\mathrm{CO}_{3}{ }^{2-}\right]+20.26$
$\mathrm{Mg} / \mathrm{Ca}=0.19^{*} \mathrm{Temp}+7.64 \times 10^{-10 *} \Delta\left[\mathrm{CO}_{3}{ }^{2-}\right]+2.54 \times 10^{-8}$
$\mathrm{Sr} / \mathrm{Ca}=2.48 \times 10^{-9 *} \mathrm{Temp}+0.022{ }^{*} \Delta\left[\mathrm{CO}_{3}{ }^{2-}\right]+0.25$

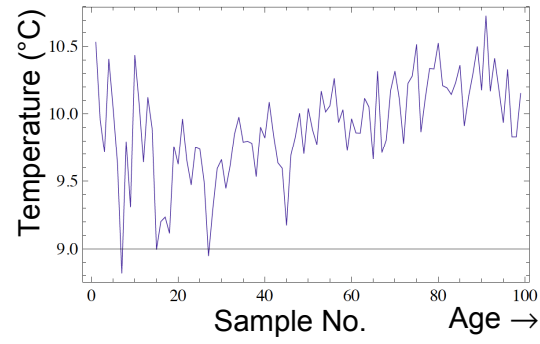

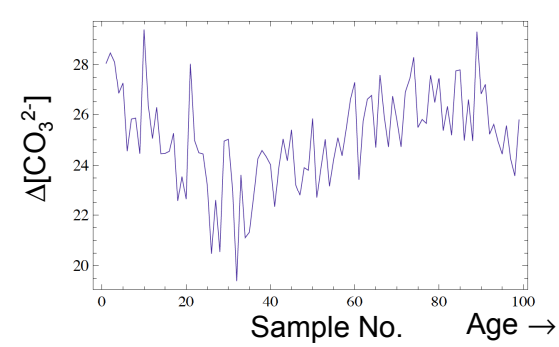

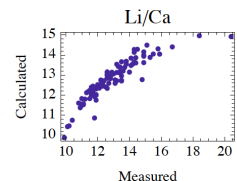

Measured $\mathrm{Mg} / \mathrm{Ca}$

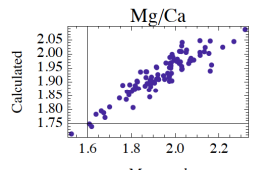

Measured

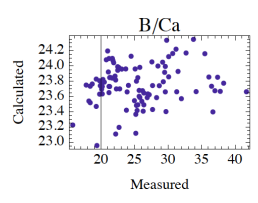

$\mathrm{Sr} / \mathrm{Ca}$

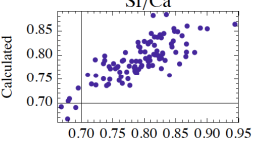

Measured

\section{Solution 2:}
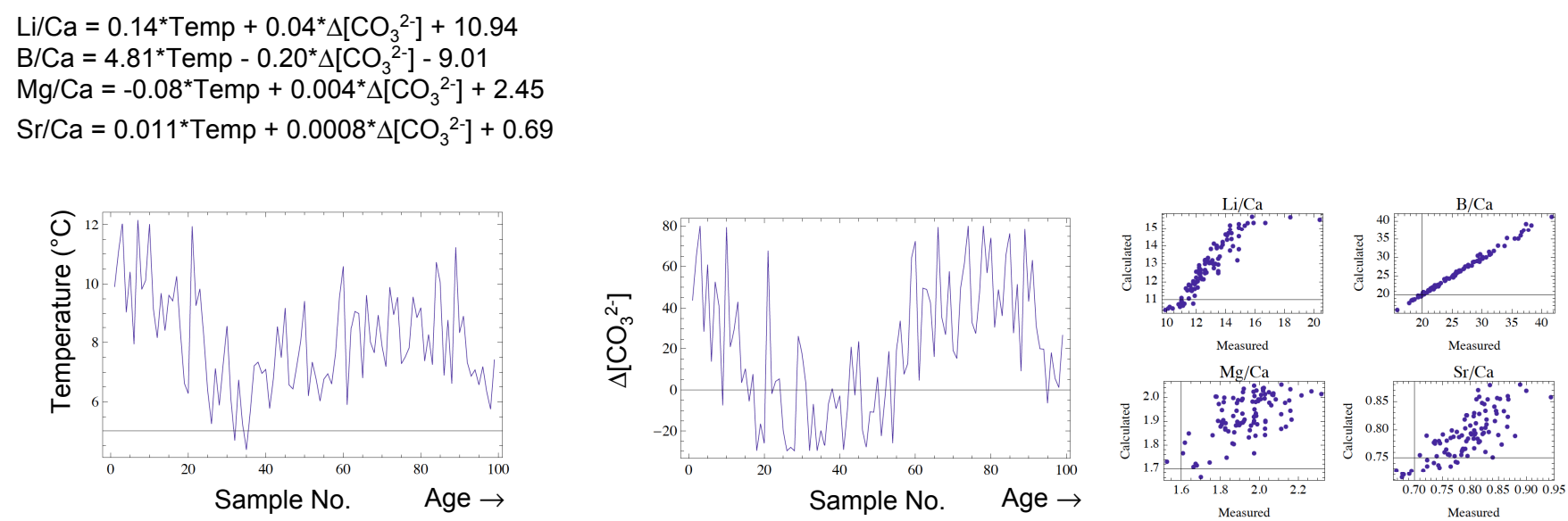

Fig. 4. Examples of $O$. umbonatus X/Ca multiple regression solutions determined from global minimization. For each solution, the temperature and bottom water $\Delta\left[\mathrm{CO}_{3}^{2-}\right]$ regression coefficients are shown, together with the downcore temperature and bottom water $\Delta\left[\mathrm{CO}_{3}^{2-}\right]$ reconstructions and cross plots of the calculated (estimated from global minimization) and measured (actual) X/Ca.

$\Delta\left[\mathrm{CO}_{3}^{2-}\right]$ and temperature using the Nelder-Mead algorithm, we compute the values of these parameters and element ratio regression coefficients that minimize the sum of the squared difference between the actual measured element ratios and predicted values (i.e. a global minimum solution). We appreciate that other environmental parameters may contribute to O. umbonatus $\mathrm{X} / \mathrm{Ca}$ (e.g. preservation, seawater $\mathrm{X} / \mathrm{Ca}$ ), but at present, the form of these relationships is unclear and there are substantial uncertainties in the downcore records of these parameters. The global minimization technique is sensitive to outlying data points; therefore, we restrict the dataset to remove large amplitude, high-frequency variability that is unsupported by two or more data points.

We find that there are several solutions to the Site 1209 dataset that provide estimates of middle Eocene temperature and $\Delta\left[\mathrm{CO}_{3}^{2-}\right]$ that are consistent with existing proxy constraints. No single solution consistently and accurately replicated all four of the measured $\mathrm{X} / \mathrm{Ca}$ ratios. One solution provided consistent estimates for $\mathrm{Li} / \mathrm{Ca}, \mathrm{Mg} / \mathrm{Ca}$ and $\mathrm{Sr} / \mathrm{Ca}$ across a range of values, although the accuracy was poor and $\mathrm{B} / \mathrm{Ca}$ ratios were poorly replicated (example solution 1 in Fig. 4). In some solutions, the $\mathrm{Li} / \mathrm{Ca}$ and $\mathrm{B} / \mathrm{Ca}$ values were replicated very well, but the $\mathrm{B} / \mathrm{Ca} \Delta\left[\mathrm{CO}_{3}^{2-}\right]$ regression coefficient and/or the $\mathrm{Mg} / \mathrm{Ca}$ temperature coefficients were negative (example solution 2 in Fig. 4), which is the opposite relationship to existing core top data for $O$. umbonatus and other benthic species (e.g. this study, Lear et al., 2000, 2002; Healey et al., 2008; Yu and Elderfield, 2007). None of the solutions replicated the $\mathrm{X} / \mathrm{Ca}-\Delta\left[\mathrm{CO}_{3}^{2-}\right]$ coefficients based on core top regressions (Dawber and Tripati, 2012).

The lack of a congruent solution likely reflects the limitation of our assumptions that $\mathrm{X} / \mathrm{Ca}$ estimates in $O$. umbonatus are influenced by only two parameters and/or the X/Ca temperature and $\Delta\left[\mathrm{CO}_{3}^{2-}\right]$ regression coefficients are constant throughout the middle Eocene. Secondary diagenesis and changes in seawater composition are additional parameters that may influence $\mathrm{X} / \mathrm{Ca}$ in $O$. umbonatus and may need to be factored into the regression models. Global minimization 
of foraminifera multi-element ratio data is still a potentially powerful paleoproxy tool, but additional studies examining downcore data with better constrained hydrographic and carbonate chemistry histories are need to access the utility of this method.

\subsection{Possible implications for middle Eocene climate}

The lack of a consistent correlation between all four records throughout the middle Eocene likely indicates that additional parameters are influencing the $\mathrm{Li} / \mathrm{Ca}, \mathrm{B} / \mathrm{Ca}$ and $\mathrm{Sr} / \mathrm{Ca}$ records and that the processes linking the records are complex. The O. umbonatus $\mathrm{Sr} / \mathrm{Ca}$ record exhibits the most striking correlation with the seawater $\delta^{18} \mathrm{O}$ reconstruction, but, as discussed, the relationship is opposite to what might be expected if $O$. umbonatus $\mathrm{Sr} / \mathrm{Ca}$ were controlled by seawater composition related to shelf aragonite recrystallisation. If $O$. umbonatus $\mathrm{Sr} / \mathrm{Ca}$ ratios are primarily governed by bottom water $\Delta\left[\mathrm{CO}_{3}^{2-}\right]$, the reconstructions imply that, during middle Eocene glacial intervals, carbonate saturation was reduced at Site 1209. Detailed records of $\mathrm{CaCO}_{3}$ mass accumulation rates (MARs) for Sites 1218 and 1219 (Lyle et al., 2005; Tripati et al., 2005), and a compilation of carbonate content for other tropical Pacific sites have been interpreted to record increased deep water carbonate preservation associated with glacial expansion (ca. 41.5 Ma), as a result of a deepening of the saturation horizon (ca. 41.5 Ma; Lyle et al., 2005; Tripati et al., 2005). The apparent discrepancy between records from Site 1209 and other Pacific sites may reflect local differences in carbonate saturation due to variations in the carbon rain rate and ventilation. It is also possible that the lysocline and CCD were decoupled during the middle Eocene (Site 1209 would have been closest to the paleo-lysocline). Alternately, O. umbonatus $\mathrm{Sr} / \mathrm{Ca}$ ratios may not primarily reflect changes in bottom water $\Delta\left[\mathrm{CO}_{3}^{2-}\right]$. None of the $\mathrm{X} / \mathrm{Ca}$ records exhibit a close correspondence with paleo- $p \mathrm{CO}_{2}$ estimates (Fig. 3), but this observation may reflect several causes, including the different temporal resolution of the records, uncertainties associated with all proxy reconstructions and the additional processes influencing bottom water $\Delta\left[\mathrm{CO}_{3}^{2-}\right]$.

\section{Conclusions}

Detailed records of O.umbonatus $\mathrm{Li} / \mathrm{Ca}, \mathrm{B} / \mathrm{Ca}, \mathrm{Mg} / \mathrm{Ca}$ and $\mathrm{Sr} / \mathrm{Ca}$ from ODP Site 1209 exhibit well-defined and large amplitude shifts on a number of timescales during the middle Eocene. Bottom water $\Delta\left[\mathrm{CO}_{3}^{2-}\right]$ may influence $\mathrm{X} / \mathrm{Ca}$; however, discrepancies in the nature and magnitude of downcore $\mathrm{X} / \mathrm{Ca}$ records at Site 1209 suggest that either empirically derived core top regression models are not appropriate for the early Cenozoic and/or X/Ca records are influenced by secondary parameters. The $O$. umbonatus $\mathrm{Mg} / \mathrm{Ca}$ record for Site 1209 is consistently different to the $\mathrm{Li} / \mathrm{Ca}, \mathrm{B} / \mathrm{Ca}$ and $\mathrm{Sr} / \mathrm{Ca}$ records suggesting that bottom water $\Delta\left[\mathrm{CO}_{3}^{2-}\right]$ is not the dominant control on $\mathrm{Mg} / \mathrm{Ca}$ ratios for this species. This hypothesis is supported by the order of magnitude difference in the relative sensitivity of $O$. umbonatus $\mathrm{Mg} / \mathrm{Ca}$ to temperature and $\Delta\left[\mathrm{CO}_{3}^{2-}\right]$, as determined from multiple linear regression. An incomplete understanding of the controls on elemental incorporation into benthic foraminifera hinders our ability to confidently quantify changes in saturation state using single $\mathrm{X} / \mathrm{Ca}$ reconstructions over timescales ranging from the LGM to early Cenozoic. Additional culturing work and downcore multi-element studies are required to further assess the potential of $\mathrm{X} / \mathrm{Ca}$ ratios as proxy archives for bottom water $\Delta\left[\mathrm{CO}_{3}^{2-}\right]$.

Acknowledgements. The authors gratefully acknowledge L. Booth, M. Greaves, and J. Day for providing technical assistance, members of the Department of Earth Sciences at Cambridge for discussions of this work, and thoughtful comments from the reviewers and editor on earlier versions of this manuscript. C. F. D. was funded by a NERC studentship. A. K. T. was supported at UCLA by a Hellman Fellowship and a UCLA FRG grant, as well as a NERC Postdoctoral Fellowship and a Junior Research Fellowship from Magdalene College at the University of Cambridge. This research used samples and data provided by the Ocean Drilling Program (ODP).

Edited by: E. Wolff

\section{References}

Archer, D. E.: Equatorial Pacific calcite preservation cycles: production or dissolution, Paleoceanography, 65, 561-571, 1991.

Archer, D., Emerson, S., and Reimers, C.: Dissolution of calcite in deep-sea sediments: $\mathrm{pH}$ and $\mathrm{O}_{2}$ microelectrode results, Geochim. Cosmochim. Ac., 53, 2831-2845, doi:10.1016/00167037(89)90161-0, 1989.

Balter, V., Lécuyer, C., and Barrat, J. A.: Reconstructing seawater $\mathrm{Sr} / \mathrm{Ca}$ during the last $70 \mathrm{My}$ using fossil fish tooth enamel, Palaeogeogr. Palaeocl., 310, 133-138, doi:10.1016/j.palaeo.2011.02.024, 2011.

Barker S., Greaves, M., and Elderfield, H.: A study of cleaning procedures used for foraminiferal $\mathrm{Mg} / \mathrm{Ca} \mathrm{pa}-$ leothermometry, Geochem. Geophys. Geosyst, 4, 8407, doi:10.1029/2003GC000559, 2003.

Billups, K. and Schrag, D.: Application of benthic foraminiferal $\mathrm{Mg} / \mathrm{Ca}$ ratios to questions of Cenozoic climate change, Earth Planet. Sc. Lett., 209, 181-195, 2003.

Bohaty, S. M., Zachos, J. C., Florindo, F., and Delaney, M.: Coupled greenhouse warming and deep-sea acidification in the middle Eocene, Paleoceanography, 24, PA2207, doi:10.1029/2008PA001676, 2009.

Bralower, T.: Data report: Paleocene-early Oligocene calcareous nannofossil biostratigraphy, ODP Leg 198 Sites 1209, 1210, and 1211 Shatsky Rise, Pacific Ocean, Proceedings of the Ocean Drilling Program: Scientific Results, 198, 2005.

Broecker, W. S. and Peng, T. H.: Tracers in the Sea, Eldigio Press, 1982. 
Brown, R. E., Anderson, L. D., Thomas, E., and Zachos, J. C.: A core-top calibration of $\mathrm{B} / \mathrm{Ca}$ in the benthic foraminifers Nuttallides umbonifera and Oridorsalis umbonatus: A proxy for Cenozoic bottom water carbonate saturation, Earth Planet. Sc. Lett., 310, 360-368, doi:10.1016/j.eps1.2011.08.023, 2011.

Browning, J., Miller, K., and Pak, D.: Global implications of lower to middle Eocene sequence boundaries on the New Jersey coastal plain: The icehouse cometh, Geology, 247, 639-642, 1996.

Bryan, S. P. and Marchitto, T. M.: Mg/Ca-temperature proxy in benthic foraminifera: New calibrations from the Florida Straits and a hypothesis regarding $\mathrm{Mg} / \mathrm{Li}$, Paleoceanography, 232, PA2220, doi:10.1029/2007PA001553, 2008.

Coggon, R. M., Teagle, D. A. H., Smith-Duque, C. E., Alt, J. C., and Cooper, M. J.: Reconstructing past seawater $\mathrm{Mg} / \mathrm{Ca}$ and $\mathrm{Sr} / \mathrm{Ca}$ from mid-ocean ridge flank calcium carbonate veins, Science, 327, 1114-1117, 2010.

Corliss, B. H.: Microhabitats of benthic foraminifera within deepsea sediments, Nature, 314, 435-438, 1985.

Coxall, H. K. and Wilson, P. A.: Early Oligocene glaciation and productivity in the eastern equatorial Pacific: Insights into global carbon cycling, Paleoceanography, 26, PA2221, doi:10.1029/2010PA002021, 2011.

Coxall, H. K., Wilson, P. A., Palike, H., Lear, C. H., and Backman, J.: Rapid stepwise onset of Antarctic glaciation and deeper calcite compensation in the Pacific Ocean, Nature, 433, 53-57, 2005.

Dawber, C. F. and Tripati, A.: Constraints on glaciation in the middle Eocene 46-37 Ma from Ocean Drilling Program ODP Site 1209 in the tropical Pacific Ocean, Paleoceanography, 26, PA2208, doi:10.1029/2010PA002037, 2011.

Dawber, C. F. and Tripati, A.: Relationships between bottom water carbonate saturation and element/Ca ratios in coretop samples of the benthic foraminifera Oridorsalis umbonatus, Biogeosciences, 9, 3029-3045, doi:10.5194/bg-9-3029-2012, 2012.

Dawber, C. F., Tripati, A., Gale, A., MacNiocaill, C., and Hesselbo, S.: Glacioeustasy during the middle Eocene? Insights from the stratigraphy of the Hampshire Basin, UK, Palaeogeogr. Palaeoclim., 300, 84-100, 2011.

DeConto, R. and Pollard, D.: Rapid Cenozoic glaciation of Antarctica induced by declining atmospheric $\mathrm{CO}_{2}$, Nature, 421, 245249, 2003.

DeConto, R., Pollard, D., Wilson, P. A., Palike, H., Lear, C. H., and Pagani, M.: Thresholds for Cenozoic bipolar glaciation, Nature, 455, 652-656, 2008.

de Villiers, S., Greaves, M., and Elderfield, H.: An intensity ratio calibration method for the accurate determination of $\mathrm{Mg} / \mathrm{Ca}$ and $\mathrm{Sr} / \mathrm{Ca}$ of marine carbonates by ICP-AES, Geochem. Geophys. Geosys., 3, 1525-2027, 2002.

Dutton, A., Lohmann, K. C., and Leckie, R. M.: Insights from the Paleogene tropical Pacific: Foraminiferal stable isotope and elemental results from Site 1209, Shatsky Rise, Paleoceanography, 20, PA3004, doi:10.1029/2004PA001098, 2005.

Edgar, K. M., Wilson, P. A., Sexton, P. F., and Suganuma Y.: No extreme bipolar glaciation during the main Eocene calcite compensation shift, Nature, 448, 908-911, 2007.

Ekart, D. D., Cerling, T. E., Montañez, I. P., and Tabor, N. J.: A 400 million year carbon isotope record of pedogenic carbonate: Implications for paleoatmospheric carbon dioxide, Am. J. Sci., 299, 805-827, 1999.
Elderfield, H., Yu, J., Anand, P., Kiefer, T., and Nyland, B.: Calibrations for benthic foraminiferal $\mathrm{Mg} / \mathrm{Ca}$ paleothermometry and the carbonate ion hypothesis, Earth Planet. Sc. Lett., 250, 633-649, doi:10.1016/j.eps1.2006.07.041, 2006.

Emerson, S. and Bender, M.: Carbon fluxes at the sediment-water interface of the deep-sea: Calcium carbonate preservation, J. Mar. Res, 391, 139-162, 1981.

Erez, J.: The Source of Ions for Biomineralization in Foraminifera and Their Implications for Paleoceanographic Proxies, Rev. Mineral. Geochem., 541, 115-149, 2003.

Erez, J., Bentov, S., Tishler, C., and Szafranek, D.: Intracellular calcium storage and the calcification mechanism of perforate foraminifera (abstract), Paleo. Bios., 16, p. 30, 1994.

Fantle, M. S. and DePaolo, D. J.: Variations in the marine Ca cycle over the past 20 million years, Earth Planet. Sc. Lett., 2371-2372, 102-117, 2005.

Freeman, K. and Hayes, J.: Fractionation of carbon isotopes by phytoplankton and estimates of ancient $\mathrm{CO}_{2}$ levels, Global Biogeochem. Сy., 62, 185-198, 1992.

Gaetani, G. and Cohen, A.: Element partitioning during precipitation of aragonite from seawater: A framework for understanding paleoproxies, Geochem. Cosmochim. Ac., 70, 4617-4634, 2006.

Gaetani, G., Cohen, A., Wang, Z., and Crusius, J.: Rayleigh-based, multi-element coral thermometry: A biomineralization approach to developing climate proxies, Geochem. Cosmochim. Ac., 75, 1920-1932, 2011.

Griffith, E. M., Paytan, A., Caldeira, K., Bullen, T. D., and Thomas, E.: A Dynamic Marine Calcium Cycle During the Past 28 Million Years, Science, 322, 1671, doi:10.1126/science.1163614, 2008.

Gross, O.: Influence of temperature, oxygen and food availability on the migrational activity of bathyal benthic foraminifera: evidence by microcosm experiments, Hydrobiologia, 4261, 123137, 2000.

Hall, J. M. and Chan, L. H.: Li/Ca in multiple species of benthic and planktonic foraminifera: thermocline, latitudinal, and glacial-interglacial variation, Geochim. Cosmochim. Ac., 683, 529-545, 2004.

Hancock, H. J. L. and Dickens, G. R.: Carbonate Dissolution Episodes in Paleocene and Eocene sediment, Shatsky Rise, WestCentral Pacific, in: Proceedings of the Ocean Drilling Program, Scientific Results , 198, 2005.

Healey, S. L., Thunell, R. C., and Corliss, B. H.: 2008 The Mg/Catemperature relationship of benthic foraminiferal calcite: New core-top calibrations in the $<4{ }^{\circ} \mathrm{C}$ temperature range, Earth Planet. Sc. Lett., 2723-2724, 523-530, 2008.

Heiri, O., Lotter, A. F., and Lemcke, G.: Loss on ignition as a method for estimating organic and carbonate content in sediments: reproducibility and comparability of results, J. Paleolimnol., 251, 101-110, 2001.

Horita, J., Zimmerman, H., and Holland, H.: Chemical evolution of seawater during the Phanerozoic: Implications from the record of marine evaporates, Geochim. Cosmochim. Ac., 66, 3733-3756, 2002.

Kurschner, W. M., Wagner, F., Dilcher, D. L., and Visscher, H.: Using fossil leaves for the reconstruction of Cenozoic paleoatmospheric $\mathrm{CO}_{2}$ concentrations, in: Geological Perspectives of Global Climate Change, edited by: Gerhard, L. C., Harrison, W. E., and Hanson, B. M., APPG Stud. Geol., 47, 169-189, 2001. 
Lear, C. and Rosenthal, Y.: Benthic foraminiferal Li/Ca: Insights into Cenozoic seawater carbonate saturation state, Geology, 3411, 985-988, 2006.

Lear, C. H., Elderfield, H., and Wilson, P.: Cenozoic deep-sea temperatures and global ice volumes from $\mathrm{Mg} / \mathrm{Ca}$ in benthic foraminferal calcite, Science, 287, 269-272, 2000.

Lear, C. H., Rosenthal, Y., and Slowey, N.: Benthic foraminiferal $\mathrm{Mg} / \mathrm{Ca}$-paleothermometry: A revised core-top calibration, Geochim. Cosmochim. Ac., 6619, 3375-3387, 2002.

Lear, C. H., Elderfield, H., and Wilson, P.: A Cenozoic seawater $\mathrm{Sr} / \mathrm{Ca}$ record from benthic foraminiferal calcite and its application in determining global weathering fluxes, Earth Planet. Sc. Lett., 2081-2, 69-84, 2003.

Lear, C. H., Rosenthal, Y., Coxall, H. K., and Wilson, P. A.: Late Eocene to early Miocene ice sheet dynamics and the global carbon cycle, Paleoceanography, 194, 1-11, 2004.

Lear, C. H., Mawbey, E. M., and Rosenthal, Y.: Cenozoic benthic foraminiferal $\mathrm{Mg} / \mathrm{Ca}$ and $\mathrm{Li} / \mathrm{Ca}$ records: Toward unlocking temperatures and saturation states, Paleoceanography, 254, PA4215, doi:10.1029/2009PA001880, 2010.

Lowenstein, T. K., Timofeeff, M. N., Brennan, S. T., Hardie, L. A., and Demicco, R. V.: Oscillations in Phanerozoic seawater chemistry: Evidence from fluid inclusions in salt deposits, Science, 294, 1086-1088, doi:10.1126/science.1064280, 2001.

Lyle, M., Olivarez Lyle, A., Backman, J., and Tripati, A.: Biogenic sedimentation in the Eocene equatorial Pacific-the stuttering greenhouse and Eocene carbonate compensation depth, in: Proc. ODP, Sci. Results, 199: College Station, TX (Ocean Drilling Program), edited by: Wilson, P. A., Lyle, M., and Firth, J. V., 1-35, doi:10.2973/odp.proc.sr.199.219.2005, 2005.

Marchitto, T. M., Bryan, S. P., Curry, W. B., and McCorkle, D. C.: $\mathrm{Mg} / \mathrm{Ca}$ temperature calibration for the benthic foraminifer Cibicidoides pachyderma, Paleoceanography, 22, PA1203, doi:10.1029/2006PA001287, 2007.

Marriott, C. S., Henderson, G. M., Crompton, R., Staubwasser, M., and Shaw, S.: Effect of mineralogy, salinity, and temperature on $\mathrm{Li} / \mathrm{Ca}$ and $\mathrm{Li}$ isotope composition of calcium carbonate, Chem. Geol., 2121-2122, 5-15, 2004.

Martin, P. A., Lea, D. W., Mashiotta, T. A., Papenfuss, T., and Sarnthein, M.: Variation of foraminiferal Sr/Ca over Quaternary glacial-interglacial cycles: Evidence for changes in mean ocean Sr/Ca?, Geochem. Geophys. Geosyst., 1, 1004, doi:10.1029/1999GC000006, 1999.

Martin, W. and Sayles, F.: $\mathrm{CaCO}_{3}$ dissolution in sediments of the Ceara Rise, western equatorial Atlantic, Geochim. Cosmochim. Ac., 60, 233-263, 1996.

McElwain, J. C.: Do fossil plants signal palaeoatmospheric carbon dioxide concentration in the geological past?, Philos. T. R. Soc. B, 353, 83-96, 1998

Merico, A., Tyrrell, T., and Wilson, P. A.: Eocene/Oligocene ocean de-acidification linked to Antarctic glaciation by sea-level fall, Nature, 452, 979-983, 2008.

Miller, K., Kominz, M. A., Brwning, J. V., Mountain, G. S., Katz, M. E., Sugarman, P. J., Cramer, B. S., Christie-Blick, N., and Pekar, S. F.: The phanerozoic record of global sea-level change, Science, 310, 1293-1298, 2005.

Pagani, M., Zachos, J., Freeman, K. H., Tipple, B., and Bohaty, S.: Marked decline in atmospheric carbon dioxide concentrations during the Paleogene, Science, 309, 600-603, 2005.
Pearson, P. N., Foster, G. L., and Wade, B. S.: Atmospheric carbon dioxide through the Eocene-Oligocene climate transition, Nature, 461, 1110-1113, 2009.

Petrizzo, M. R., Premoli Silva, I., and Ferrari, P.: Data Report: Paleogene Planktonic Foraminifer Biostratigraphy, ODP Leg 198 Holes 1209A, 1210A, and 1211A Shatsky Rise, Northwest Pacific Ocean, in: Proceedings of the Ocean Drilling Program: Scientific Results, 198, 2005.

Rae, J. W. B., Foster, G. L., Schmidt, D. N., and Elliott, T.: Boron isotopes and $\mathrm{B} / \mathrm{Ca}$ in benthic foraminifera: Proxies for the deep ocean carbonate system, Earth Planet. Sc. Lett., 302, 403-413, doi:10.1016/j.epsl.2010.12.034, 2011.

Rathburn, A. and Corliss, B.: The ecology of livingstained deep-sea benthic foraminifera from the Sulu Sea, Paleoceanography, 91, 87-150, 1994.

Rathmann, S. and Kuhnert, H.: Carbonate ion effect on $\mathrm{Mg} / \mathrm{Ca}$, $\mathrm{Sr} / \mathrm{Ca}$ and stable isotopes on the benthic foraminifera Oridorsalis umbonatus off Namibia, Mar. Micropaleontol., 66, 120133, 2008.

Rathmann, S., Hess, S., Kuhnert, H., and Mulitza, S.: Mg/Ca ratios of the benthic foraminifera Oridorsalis umbonatus obtained by laser ablation from core top sediments: Relationship to bottom water temperature, Geochem. Geophys. Geosyst, 5, Q12013, doi:10.1029/2004GC000808, 2004.

Riesselman, C. R., Dunbar, R. B., Mucciarone, D. A., and Kitasei, S. S.: High resolution stable isotope and carbonate variability during the early Oligocene climate transition: Walvis Ridge ODP Site 1263: US Geological Survey and The National Academies, USGS OF-2007-1047, Short Research Paper 095, 2007.

Rosenthal, Y., Lear, C. H., Oppo, D. W., and Linsley, B. K.: Temperature and carbonate ion effects on $\mathrm{Mg} / \mathrm{Ca}$ and $\mathrm{Sr} / \mathrm{Ca}$ ratios in benthic foraminifera: Aragonitic species Hoeglundina elegans, Paleoceanography, 21, PA1007, doi:10.1029/2005PA001158, 2006.

Sexton, P. F., Wilson, P. A., and Pearson, P. N.: Microstructural and geochemical perspectives on planktic foraminiferal preservation:"Glassy" versus "Frosty", Geochem. Geophys. Geosyst., 7, Q12P19, doi:10.1029/2006GC001291, 2006.

Sosdian, S. and Rosenthal, Y.: Deep-Sea Temperature and Ice Volume Changes Across the Pliocene-Pleistocene Climate Transitions, Science, 325, 306-310, 2009.

Spofforth, D. J. A., Agnini, C., Pälike, H., Rio, D., Fornaciari, E., Giusberti, L., Luciani, V., Lanci, L., and Muttoni, G.: Organic carbon burial following the middle Eocene climatic optimum in the central western Tethys, Paleoceanography, 25, PA3210, doi:10.1029/2009PA001738, 2010.

Stoll, H. M. and Schrag, D.: Effects of Quaternary sea level cycles on strontium in seawater, Geochim. Cosmochim. Ac., 627, 11071118, 1998.

Stoll, H. M., Schrag, D. P., and Clemens, S. C.: Are seawater $\mathrm{Sr} / \mathrm{Ca}$ variations preserved in quaternary foraminifera? - An in situ study in the Panama Basin, Geochim. Cosmochim. Ac., 63, 3535-3547, 1999.

Tripati, A. K. and Elderfield, H.: The impact of changing deepwater carbonate ion on reconstructions of temperature and seawater oxygen isotope ratios, paper presented at Biogeochemical Controls on Palaeoceanographic Proxies, Geol. Soc. London, 3-4 October 2005.

Tripati, A., Backman, J., Elderfield, H., and Ferretti, P.: Eocene bipolar glaciation associated with global carbon cycle changes, 
Nature, 436, 341-346, 2005.

Tripati, A. K., Eagle, R. A., Morton, A., Dowdeswell, J. A., Atkinson, K. L., Bahe, Y., Dawber, C. F., Khadun, E., Shaw, R. M. H., Shottle, O., and Thanabalasundaram, L.: Evidence for glaciation in the Northern Hemisphere back to $44 \mathrm{Ma}$ from ice-rafted debris in the Greenland Sea, Earth Planet. Sc. Lett., 2651-2652, 112-122, 2008.

Tripati, A. K., Allmon, W. D., and Sampson, D. E.: Possible evidence for a large decrease in seawater strontium/calcium ratios and strontium concentrations during the Cenozoic, Earth Planet. Sc. Lett., 282, 122-130, doi:10.1016/j.epsl.2009.03.020, 2009.

Wilkinson, B. H. and Algeo, T. J.: Sedimentary carbonate record of calcium-magnesium cycling, Am. J. Sci., 289, 1158-1194, 1989.

Yu, J. and Elderfield, H.: Benthic foraminiferal B/Ca ratios reflect deep water carbonate saturation state, Earth Planet. Sc. Lett., 2581-2582, 73-86, 2007.
Yu, J. and Elderfield, $\mathrm{H} .: \mathrm{Mg} / \mathrm{Ca}$ in the benthic foraminifera Cibicidoides wuellerstorfi and Cibicidoides mundulus: Temperature versus carbonate ion saturation, Earth Planet. Sc. Lett., 276, 129 139, 2008.

Yu, J., Day, J., Greaves, M., and Elderfield, H.: Determination of multiple element/calcium ratios in foraminiferal calcite by quadrupole ICP-MS, Geochem. Geophys. Geosyst., 6, Q08P01, doi:10.1029/2005GC000964, 2005. 